[Afnais N. Y. Acapemy of Sciences, VoL XX, No. 5, Part II, pp. 243-294,

PlL. XIV - XV. 20 December, 1910]

\title{
THE COAL BASIN OF DECAZEVILLE, FRANCE
}

By John J. Stevenson

(Read in abstract before the Academy, 7 November, 1910)

CONTENTS

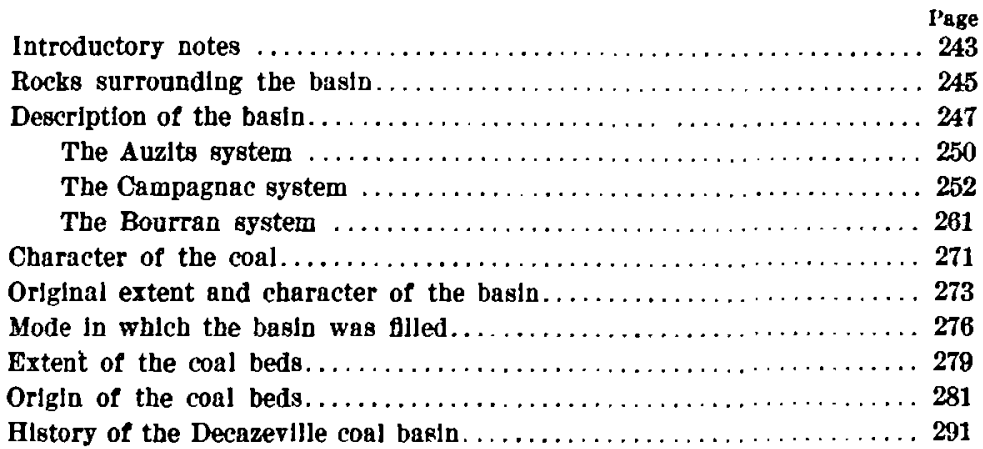

\section{INTRODUCTORY NOTES}

The Decazeville coal basin, named from the chief city within its borders, is in the department of Aveyron, about 400 miles south from Paris and about 190 miles south from Commentry. The mines, originally opened for the Duc de Decazes, have been in operation for more than a century. The proporties are controlled by two great organizations, the Compagnie anonyme de Commentry, Fourchamboult et Decazeville, with important steel works at Decazeville, and the Compagnie des Mines de Campagnac at Cransac, five miles farther south. Within a short distance from the latter city, is the widely extended area of exploitation by the Sociéte des Acieries de France, from which the greater part of the coal has been removed.

The basin is rudely triangular in form; the longer axis, from west of north to east of south, is about 12 miles long, and the width varies from nearly six miles at the south to barely one third of a mile at the north. where the coal rocks pass under deposits of early Tertiary age. The total area of Coal Measures is not far from 30 square miles, so that it is about five sixths as large as a township in Ohin. The interest attaching to the 
basin is far out of proportion to its extent; the coal beds are of unusual thickness, the plications and other disturbances are very complicated, and the conditions observed there have been regarded as arguing strongly in favor of the doctrine that coal beds have been formed from transported vegetable matter.

No elaborate description, such as that by Fayol of Commentry or that by Gruner of Saint-Etienne, has appeared respecting the basin of Decazeville; but several brief memoirs have been published, some of which are important. Blavier in 1806 described the coal, which even then had been opened at several localities; Cordier in 1809 made incidental reference to the coal beds and expressed surprise at the irregularity of their occurrence; Jufrenoy in 1841 discussed the region somewhat in detail ; Boisse in $18 \% 0$ differentiated the deposits and grouped thern into two systems, while suggesting that there may be three. Somewhat later, Grand' Eury investigated the Coal Measures of this basin from the viewpoint of paleobotany and made correlations with other areas.

The first systematic statement known to the writer was given by Bergeron $^{1}$ at the reunion of the Geological Society in l'Allier. He recognized three systems of deposits and described the method by which the basin was filled and the roal beds formed, applying the doctrine of deltas as announced by Fayol in the preceding vear. This paper was accompanied by a preliminary map, showing the positions of three deltas. His memoir, published in the following year, defined sharply the three systems of rocks, to which the terms Auzits, Campagnac and Boursan were applied. The conclusions throughout are the same as those in the earlier paper, of which this is but an elaboration, in so far as it relates to the Decazeville area. Three years later, the properties near the city of Decazeville passed into the possession of the Compagnie de Commentry et Fourchambault, and, under direction of M. Fayol, the engineers of that company began -arefol researches throughout the basin, which still continue.

In 1900, an extremely important memoir appeared, ${ }^{2}$ in which the authors summed up the results of studies made by Jardel and Picandet and their associate engineers, as complementary to the work done by Bergeron prior to the consolidation of the properties. It explains the relatlons of the three systems, the mode in which the basin was filled, the sources of

\footnotetext{
${ }^{1}$ J. Berghon : "Note aur les bakrlus boullers de Gralagersac et de Decazeville," Bull. soce. Geol de France, 3me. Ser., t. xvl, p. 1032. This contalns detalled reference to the work of his predecessors.

-. - "Etude du massif ancies situe ail aud du Plateau central," Ann. des Scl. (jéol., t. 22, p. 190.

${ }^{2}$ J. Berokron, (A) Jauspi. et i'icandft. "Etude geologique du bagsin houllier de becnzeville (Aveyron)." Bult. Soc. Grol. de France. 3me. Ser. T. xxrllt. pp. 715-748. mnn and plate of sections.
} 
the materials, the directions of the contributing streams, the development and the interferences of the little deltas during advance from the shore. This adinirable synopsis has been utilized throughout by the writer; its (lear descriptions enabled him to pass rapidly over some portions, rendered unnecessary the examination of others and made possible the practical confining of his attention to localities in which the phenomena of coal accumulation are shown most notably. ${ }^{3}$

\section{ROCKS SURROLNDING THE JBASIN}

long ago, it was recognized that the basin of Decazeville, like those on the central plateau, occupied a depression in Archean rocks; the mica schists with granite being continuous from the Commentry to the Decazeville basin. But patches of other rocks exist, whose distribution on the borders is of great importance to one endeavoring to trace the history of the area. Bergeron in his first paper gave some notes respecting these rocks, but the later memoir by Bergeron, Jardel and Picandet gives in detail their distribution along the approximately 30 miles of contour. A synopsis of their statement is essential. though the relations are shown on the accompanying map," page 246 .

The prevailing rock is mica schist. containing here and there some granulite and occasionally becoming gneiskoid. Ciranite appears at the sonthwest, and, on the western side, a narrow strip of gneiss extends northward from the southern houndary for about four miles. Just beyond is a mass of granite, sharply defined as if by a fault at the west, which is about half a mile wide and three miles long, extending almost to the Riou Wort and showing on its eastern side a very narrow strip of mica schist. I small area of microgranulite is cut by the Riou Mort. At a little way north from that stream. one reaches andesite which extends to the northarn end of the basin, forming the western boundary for about four miles.

Indesite forms the eastern boundary also to beyond the Lot River. It is almost continuous arross the hasin at the extreme north, but it has suffered great and irregular erosion in the broad valley of the Lot, and the Coal Measures reach eastward to the mica schists. These form the boundary for somewhat more than four miles, to be sucreeded by grani-

\footnotetext{
- I muat express my high apprectation of courtesies received from M. I Fayol, Dlrecfor of the comp. Anon. de Commentry, etc., M. A. Jardel, Director of that company's miney in the Decazeville basin. and $M$. F. Brocard, the metallurgleal engtneer of the company. as well as from M. Salot-Martin, geometrician of the Campagnac company. The generous asiatance glven by these offlelals makes me regret keenly that the studjes at Decagefille compel me to the belief that the coals of that hasin. like those of commentry, are of in situ orlgin.

This map has been taken from the memolr by Bergeron. Iardel and Ilcandet: the seale has hepn reduced alightly. hut no change has been mate in the geologs
} 


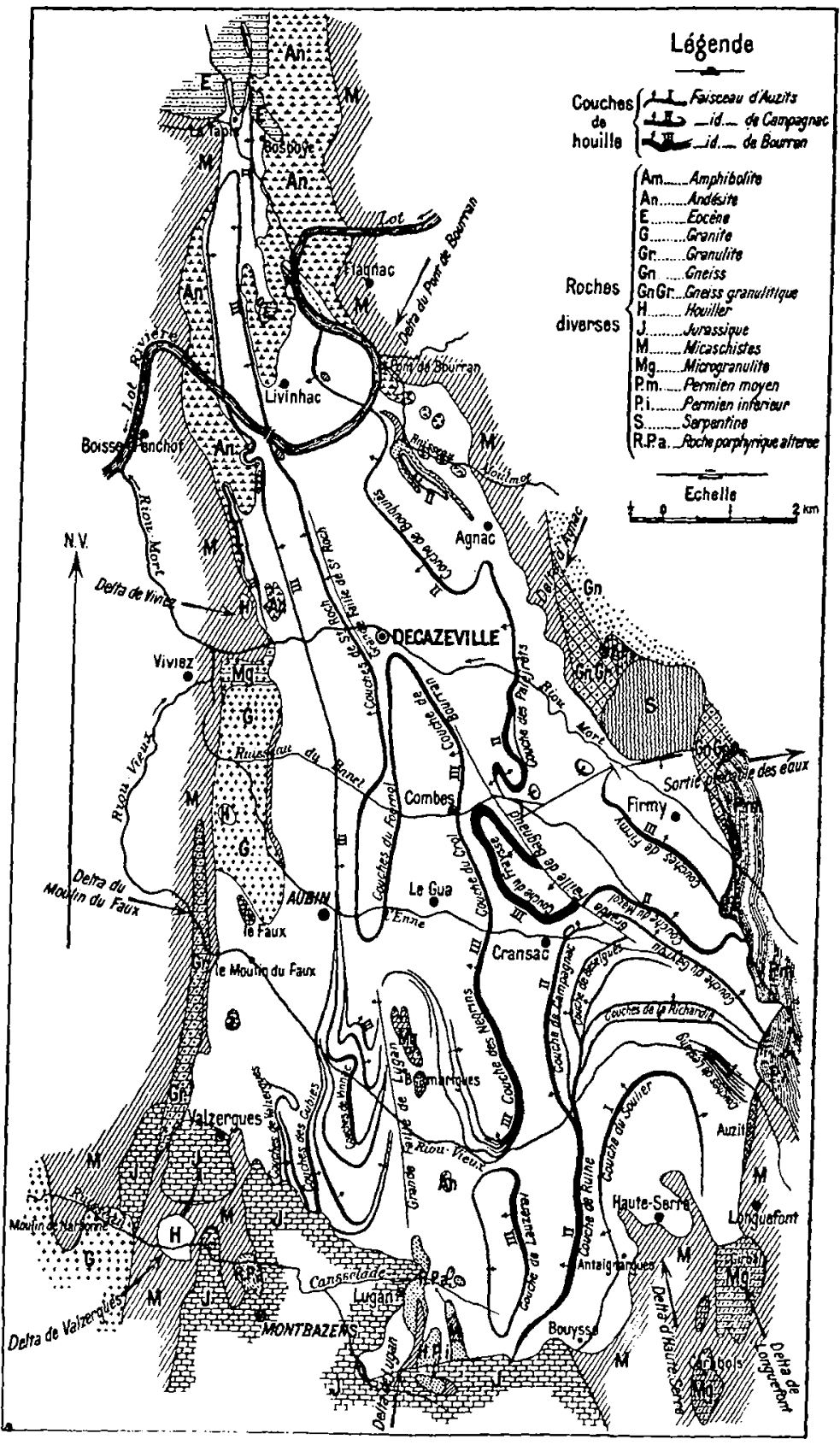

MAP OF THE COAL BABIN OF DECAZEVILLE.

Reproduced with slight reduction from the memolr by Bergeron, Jardel and Picandet. 
toid gneiss, in which is implanted a boss of serpentine. These rocks are well shown in the valley of Riou Mort, being reached at only a few rods from the stream. Opposite the village of Firmy, one finds Permian beds, which are the boundary thence for four miles to the end of the ridge overlooking Auzits, where they rest on the mica schist. From Auzits southward and then westward, mica schist is probably the boundary rock, though for nearly two thirds of the distance along the southern border, an irregular line of more than six miles, it is covered by Jurassic beds. In the southeast corner are some patches of microgranulite, whose relations should be well fixed in mind, as fragments derived from those patches gave the first positive clue to the mode in which the basin was filled.

One finds occasionally within the basin fragmentary areas of rocks belonging to the boundary types. Two small patches of Jurassic remain in the southwest at one and three miles from the outcrop. Permian is present in the region south from Decazeville to beyond the Ruisseau de l'Enne. Midway along the southern boundary, some bosses of a "roche porphyrique alterée" project into the Coal Measures, and a similar rock appears in small quantity at several places beyond the border of the basin. These bosses are in line with islets of andesite and microgranulite, the last of which is more than four miles from the southern boundary.

Aside from these rocks, one finds indicated on the map a small area of Coal Measures in the extreme southwest corner; another of less size on the granite, and still another on the mica schist of the western boundary.

DESCRIPTION OF THE BABIN

To determine the stratigraphical relations from surface exposures would be well nigh impossible. The region has suffered greatly from erosion, but the slopes of the hills, though usually rather steep, rarely give any but fragmentary exposures; while side cuttings on the well-graded roads are too widely separated to yield satisfactory information respecting an area which is closely folded and is slashed by faults. The great open workings, termed "découvertes," and the extensive underground developments have provided material for determination of the structure. The conditions are far less simple than in les Pegauds of Commentry, where the coal accumulated in a wholly insignificant area.

The cutting to which the present topography is due was determined by the Lot River, which crosees the north end by a tortuous course. The Riou Mort, Ruisseau Banel, Ruisseau de l'Enne and the Riou Vieux, draining the basin, unite heyond the western boundary near Viviez and enter the Iot River within three miles. The course of that river within the basin seems to have some relation with the distribution of andesite, 
while that of Riou Vieux at the southeast appears to owe its direction in great measure to the distribution of rocks in that region. This erosion is later than the middle Tertiary and, by most writers, is referred to the Quaternary. All phenomena testify to its recent origin. The valleys, for the most part, are narrow and the hill slopes are abrupt, while the summits are clearly remnants of a plain. The granitic rock on the west side has yielded much the same topography as that of the Coal Measures area. The steep hillsides rnust have been captured early by vegetation, as they show comparatively little gashing.

The later work of removal has been confined chiefly to corrasion, and erosion has done comparatively little toward leveling the region. But a long-anterior erosion, probably preceding the Jurassic and following the time of folding and faulting, removed the Permian and newer portions of the Coal Measures from much of the besin and exposed the oldest deposits in the southeast. The Quaternary erosion increased the area in which the early beds reach the surface; while trenching of the basin by valleys 400 to 600 feet deep has made the coals accessible at many places and rendered possible those mining operations which have attained so great economical importance.

Boisse, forty years ago, recognized at least two distinct systems of deposits and suggested that the succession might be divided into three. Bergeron, twenty years ago, determined the three systems, Auzits, Campagnac and Bourran. This division may not be supported strongly by paleontological evidence, but it is sufficiently distinet, for the physical conditions are unlike in the several systems.

The Auzits system consists of a succession of conglomerates, sandstones and some shales, the materials having come almost wholly from the southern border. These deposits have been exposed by erosion, and they pass under the newer rocks at a very short distance north from the Riou Vieux; but the upper beds are at the surface in the valley of Riou Mort, on the eastern border. This system includes toward the base the SoulierAbiracs coal bed and, apparently higher, the unimportant coal deposits north from Auzits known as the beds of l'Estang.

The Campagnac sygtem, heginning with the coal bed known as Rulhe, Campagnac, Paleyrets. Bouquies, in the several localities where it is worked, consists very largely of conglomerates with some sandstones and shales. Its rocks are exposed in much of the eastern half of the basin. and the great coal bed at the bottom is mined at many places. The conglomerates are shown frequently on the roads and, though the composition varies. the features are such as to show that substantially the same phreical conditions prevailed along most of the streams which supplied 
the material. The deposit of conglomerate began very soon after accumulation of the Campagnac coal bed.

The Bourran system, beginning with the Grande Couche de Bourran, known as Negrins, Crol, Fraysse, Firmy, Bourtan, Saint-Roch at the several mines, consists of shales and shaly sandstones succeeded by a considerable thickness of coarse, more or less conglomeratic sandstone. It occupies the central and western parts of the basin; and a small area, caught in the jaws of faults, remains on the eastern side near Firmy. The studies by Bergeron, Jardel and Picandet leave little room for doubting that practically all of the water-carried deposits west from the central line of the basin date from the beginning of the Bourran system.

The Decazeville basin, unlike that of Commentry, is characterized by great irregularity of structure, the beds being folded and faulted in complicated fashion. The folds will be noted in the local descriptions, but the principal faults must be mentioned here that those descriptions may be clear.

The Grande Faille de Bagnaud is distinct at la Puech, the summit of the road from Firmy to Cransac, about a mile east from the latter town; but southeast from la Puech it could not be traced, as exposures thence to Auzits are indefinite; northward, however, it seems to be crossed by the Riou Banel and its existence is highly probable thence to Riou Mort at Decazeville, where a well-marked fault exists. Northeast from Cransac, the throw is sufficient to bring the Campagnac and Bourran beds to nearly the same level.

An east and west fault passes from the Bagnaul fault to the eastern border; it will be spoken of as the Firmy fault. $A$ third fault is very distinct between the outerops of the Bourran bed, northwest from Cransac. A fourth was recognized by Bergeron, Jardel and Picandet in the south-central part of the basin and designated as the Grande Faille de Ingan. These four are the only ones with extensive throw, but the mine maps and the découvertes exhibit many others of 20 to 50 feet, some of them very complicated. These, however. though numerous and perplexing to the mining engineers, need no consideration here.

The writer's detailed observations were made in the space between the Riou Mort and the Ruisseau de l'Fnne, where the coal beds have their chief development; but the southeast corner as well as the area north from Riou Mort was visited and the relations were made out. No studies were attempted along the southern border or in the southwest enrner. where investigations by Bergeron, Jardel and Picandet have made the conditions so clear that nothing except visual familiarity with the phenomena could be gained by an examination. For the localities not risited, citations will be made from the memoir by those students. 
The Auzits system of Bergeron.-The Auzits system is exposed in the southeast corner of the basin and passes under the Campagnac at a little way north from Riou Vieux. Only the highest beds are shown farther north along the eastern side, so that its full extent cannot be determined. The faults bounding the basin at the east bring the newer systems against the old rocks. The earliest deposits of the system are not shown along the road followed by the writer, as they are within the space inclosed by the Soulier outcrop. The oldest deposit assigned to this system is near Antaignargues, where a mica-schist breccia, composed of great blocks with angles barely rounded, rests on the mica schist of the region. Above this and passing over to the mica schist is a conglomerate, which has been followed for several kilometers; its fragments are smaller and much more rounded, though still breccia-like; they are mica schist, microgranulite and white quartz. This is succeeded by a conglomerate rich in microgranulite at the west, but in granulitized mica schist at the east. The overlying rock is a coarse sandstone of more or less greenish tint, becoming yellowish eastward. This contains the Soulier coal bed. The coarse rocks underlying that coal bed have an extreme thickness of 200 meters, as determined by A. Jardel.

In going northwest ard from Auzits, one finds only indefinite exposures along the road, and those are mostly sandstone. The l'Fstang coal beds are reached in somewhat more than a half-mile from the village. little is known respecting them beyond the fact that a company formed for their exploitation soon came to grief, but evidently coal is present in small quantity. The incomplete exposures show only some thin streaks of coal associated with shale, and not coarse sandstone, dipping northeastwardly at approximately 30 degrees. A similar sandstone is exposed on the opposite aide of the stream. These beds are above the middle of the Auzits system.

Iess than half a mile beyond the l'Estang property, one reaches an abandoned coal opening at about 500 feet sonth from the road. Exposures along the road are widely disconnected, and one passing along cannot determine the relations; but loose pebbles on the hillsides at several places indicate the existence of a conglomerate, which is well marked at the opening, and there is clearly an underlying sandstone which is associated with the coal bed. The opening is on the Soulier bed, the first well-defined coal deposit in the basin. The coal was not seen, as the opening is closed by mud and water, but the dip is northward at about 30 degrees. On another tributary stream, possibly half a mile farther, there was at one time an extensive group of openings from which a large quantity of coal was taken out. The works seem to have been abandoned com- 
pletely and a definite measurement of the bed cannot be obtained now; but $\mathrm{A}$. Jardel states that the bed is double, divided by a thick clay parting, and in all about 16 feet thick. The strike of the bed has been changed to almost north-south, for the openings are along the stream which flows toward the north. There is in this space a fold with sharp northward pitch, there being easterly dips on the Auzits side, northerly dips where the coal was first reached, and now on the western side distinctly westerly dip, so that the Soulier bed has an elongated curved outcrop. The thickness is such that one should expect to find the bed in a boring at a considerable distance north from Riou Vieux.

Separated from the coal bed by a sandstone rich in feldspar is an extraordinarily coarse conglomerate, broken by thin shales and, at its maximum, almost 400 feet thick as determined by A. Jardel. This, the feldspathic conglomerate of Bergeron, Jardel and Picandet, is persistent eastward to where it passes under Riou Vieux and equally persistent southward along the western side of the exposed area. It consists mostly of microgranulite pebbles, thoroughly rounded and varying from one inch to upwards of one foot in diameter, those of the largest size being very numerous. Pebbles of other rocks occur locally. Study of these fragments enabled those investigators to determine finally the source of the materials; the microgranulite came from the areas indicated on the map, the most distant being, at its southern termination, barely four miles south from Riou Vieux. This conglomerate seems to become less coarse east and west from the first coal opening observed. The sandstones and shales enclosing the l'Estang coal beds have been taken by Bergeron, Jardel and Picandet as being most probably equivalent to the upper part of the conglomerate, which has its full development at half a mile toward the west. Those students have worked out the details of the area so thoroughly by investigation of the fragments as to prove beyond question that three little streams entering near Auzits, Haute Serre and Lugan, contributed to the formation of these deposits, now exposed in an area of about three square miles, and that the course of the main or central stream during deposition of the later beds is marked distinctly by distribution of the larger fragments.

The feldspathic conglomerate is succeeded by conglomerates and shales, in all about 600 feet as determined by $A$. Jardel, which continue to the top of the system; thev are exposed here and there beyond Rion Vieux. The extreme thickness of the Auzits system is not far from 1800 feet, the measurement being marle along the line of maximum development, near the supposed course of the Haute Serre stream. The average thickness is very much less. 
The C'ampaynar systcm of Beryeron.-The deposits of the ('ampagnac system in the southeastern part of the basin are clearly a continuation of those seen within the Auzits, for study of the included fragments leaves no room for doubting that they cane from the south. The outerops of the coals give evidence of the relationship, which is not masked by the Bagnaud fault. as the sertion seems to be continuous along the eastern side to Firmy, where one reaclese the Bourran system.

Folding and subsequent erosion have removed much of the Campagnat coal bed from the southeastem corner, how much, of course, cannot be determined. But the series from the upper part of the Auzits into the Campagnac is distinctly conformable, and the dips in the Rulhe leet, as well as in its branch, Richardie, would carry the coal only a short distance alove the hills on the southerly side of Riou Vieux. The conditions justify the suggestion that the Campagnac coal bed at one time covered much of the Auzits area. 'The (ampagnac deposits were made in this southern area by the three streams already mentioned, and the character of the material shows that each was torrential and short, not more than three or at most four miles long.

The outcrop of the Campagnac coal bed extends practically to the southern edge of the basin. Near the hamlet of Rulhe, the bed is said to be irregular, tending to lens-form, and it is triple, the main bed being on top. Half a mile farther north, near where the outcrop is crossed by Riou Vieux, the intervals between the divisions increase and the lower benches show an east and west outerop as they cross the fold. Centraliy along this, they have a northward dip, showing that the fold retains its pitch in that direction. The Bagnaud fault interrupts the continuity at the north end of this area, but the condition was the same throughout, for near Cransac the outcrop of the main bed curves toward the east, to bc rut off by the fault.

On Riou Vieux, the Campagnac bed is reached just beyond the plare where the railroad from Auzits to Viviez leaves that stream. The mine has been abandoned. and no examination of the coal could be made, but it is apparently on a lower division of the bed, probably the Couche de Richardie. The overlying rocks are shale and sandstone with, at somewhat more than 30 feet above the entry, a sandstone containing much "winglomerate. At almut one third of a mile farther, one comes to the shaft of Sainte Genevieve on the main bed. No work was in process when the locality was visited, but the mine is extensive, the coal having bown removed from a rudely triangular space almost 1100 by 1700 feet. The coal is said to be 45 feet thick. An exposure at about is feet above the coal and continuing for nearly 200 feet showed shales underlying the ...mglomerate and the dip is almost somthwest at 18 to 20 degrees. 
Pits have been opened at several places between Sainte Genevieve and Cransac; near the latter place, the Compagnie des Mines de Cransac has removed the coal by open workings, or découvertes, from an extensive area, and now the mining is done in underground workings, which reach westwardly for a long distance, the coal having been taken out to a distance of more than a kilometer from the shaft. Faults are very numesous, and the coal varies from 33 to almost 100 feet in thickness.

Exposures outside of the great découvertes are so rare that any continuous section becomes interesting to the student. In going eastward along the railroad from Cransac station, one comes to a through cut in shales. These have been stripped alongside from a considerable space in order to secure the ironstone which they contain. The succession, descending, is, the thicknesses being estimated,

1. Dark shale with fronstone and streaks of coul

2. Shales, mostly hard, weatber yellowish, are gray or drah on fresh surface $\ldots \ldots \ldots \ldots \ldots \ldots \ldots \ldots \ldots \ldots \ldots \ldots \ldots$ \&

3. Shale, distorted, with Irregular patches of coal toward the

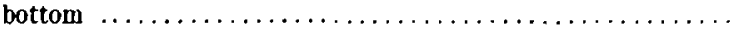

4. Shales, rather hard, dark to brown, with some streaks of black

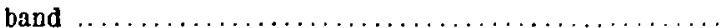

5. Shales with Ironstone and coal streaks............

6. Coal and cling, with 3 inches of fireclay helow . . . . . . . . ,

i. Shale and coal streaks..................

8. Shale, mostly drab, weathers dark ............. 20

9. Coal, Irregular, with clay parting .............. 1

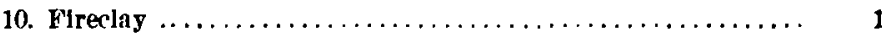

11. Shale and conglomerate kandstone, with irregular pockets of

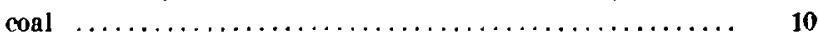

12. Conl in lenres of 12 inches thickness, mingled with fireclay... I

13. Shale and sandstone, some conglomerate...........

14. Sandstone and shale, with irregular lenses of coal........

No. 9 is thicker on the southern side of the railroad, and it is said to reach three feet at some places, but it is always irregular. The underlving shales and sandstones rise very rapidly on that side toward the east. and they are shown in somewhat distorted condition on the northerly side where the Rulhe-Cransac road crosses the railroad. The dips there are all westward, varying from 27 to 35 degress, but on the other side of the railroad, the dips in the same direction increase to 60 degrees. Evidently the axis of a fold is near, but it is not exposed. The lenses of coal in $\mathrm{Y} n$. 12 are apparently fragments of a small bed broken up during the sharp folding. No effort was made to determine the exact relations of this section, but it is in the Campagnar sy'stem at a considerable distance above the majn coal bed : judging from exposures elsewhere, the ennditions mas 
be local, but the section is of interest, as it is of the type familiar to those who work in American coal fields.

Eastward from the main outcrop, the southeast area of the Campagnac system reaches almost to the village of Firmy and covers most of the area north from Riou Vieux. The road from Auzits to Firmy follows a very tortuous line, as divides between the several streams are high and rather rugged, showing the hard conglomerates of the Campagnac system. On the ridge road, northeast from Auzits, one sees the reddish brown, more or less conglomeratic beds of the Permian resting on the mica schist. Within an eighth of a mile the Coal Measures are reached, but the exposures of conglomerate and shale are fragmentary. They belong to the Auzits system and have northeasterly dips. As one descends from the summit near la Vignerie towards la Bussière, half a mile from Cransac, he sees an occasional exposure of shale, with here and there something which resembles a coal blossom and at times a block of conglomerate shows itself. The deposits belong to the Campagnac and the traces of coal mark places of the lower subdivisions of the Campagnac bed. At la Bussière, where the road crosses the Ruisseau de l'Enne, coal has been mined, but the bed seems to be unimportant.

From la Bussière up to la Puech, the summit between Cransac and Firmy, there are many though disconnected exposures, but, in the upper part, there is an exposure of nearly 100 feet of shale, sandstone and conglomerate underlying a coal cropping near the summit. That coal seems to be the highest of the Campagnac divisions, possibly the Couche de Mazol. It underlies about 15 or 20 feet of shale on which rests a massive conglomerate. When the summit is reached at la Puech, one sees the bold conglomerate as a rounded boss descending toward Firmy. The Bagnaud fault is crossed west from the summit, but it is obscure farther toward the southeast, and it does not interfere with continuity of the section. The conglomerates of the Campagnac system are sharply defined to within half a mile of the village of Firmy.

The second important area of the Campagnac is bounded at the south by the Firmy fault. It extends continuously to the north end of the basin and is limited at the west by the outcrop of the Bourran coal bed.

Along the eastern outcrop, going northwardly from Firmy, the characteristic conglomerates of the Campagnac system appear somewhat abruptly at about half a mile from that village, the fault having been crossed near the hamlet of la Foresie. The coal bed has been opened at la Gouzinie and la Buscalie, but no work is in process. The dip at la Buscalie is not wholly definite, but it is westerly at not more than 18 degrees. The important work in process, south from Riou Mort, is at Tra- 
mont, the "découverte nouvelle," recently opened by the Decazeville company. This great excavation is at the summit of a narrow ridge and opens to both north and south.

The road southward from Decazeville to Tramont passes the grande découverte on the Bourran bed, the Bourran shaft on the same bed, as well as the broad expanse on which the Decazeville company roasts the blackband ore. Where the road turns eastward at somewhat more than a mile from Decazeville, an exposure of sandstone and conglomerate, belonging to the Campagnac system, dips westwardly at 25 to 30 degrees, and a similar dip is shown at another exposure beyond. The Campagasc coal bed has been mined for a long time along the west face of the ridge at about 250 feet above Decazeville, and work is still carried on in some of the openings. The last dip observed in coming up the hill is westward, but at the first pit reached, the dip is eastward at 55 degrees, so that a sharp fold has been crossed within 500 feet. At that pit, the coal underlies a coarse conglomerate, but at the entrance to the découverte, 100 yards beyond, the coal is covered by five to six feet of clay shale. The short through cutting which leads into the découverte shows the coal greatly disturbed, and a complex fold is displayed on the westerly wall within the quarry. As the longer axis of the découverte crosses the fold diagonally, a good section of the coal is exposed in the easterly wall, where disturbances are of limited vertical extent. The following measurements are approximately correct, as they are almost vertical to the bedding. The order is descending:

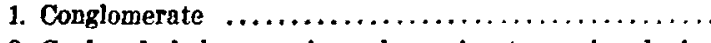

2. Coal and sbale; very irregular owing to eroslon during deposition of the overlylng rock; conl and shale layers are very distinct; but films of coal pass downward into the underlying shale as Irregular wedges.

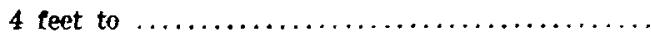

3. Clay shale; thls also bas been removed in places: It contains numerous plant Impressions with flims and lenses of conl, as well as some Iroustone.........

4. Coal, 3 to 4 Incher, black shale, 6 to 8 inches.........

5. Clay shale, somewhat contorted. contains streaks of coal, some of which come from below and extend for a foot or more across the lamina ................

6. Coal, with regular roof, many thln partinga, of apparently mineral charcoal ..................

7. Coal and arglllaceous kandrtone; 7 layers of conl and 5 of sandstone. In Rome plares, the coal layers become thln and the mass is mostly sandstone, while in others the upper sandstones disappear and the coal layers become contlnuous with the overlying

Feet Inches

50

$0 \quad 10$ 
bench. The lower 2 feet, very arglllaceous, contains many strings rising from the underlying coal and dirlding into branches. This is one of the most persistent members of the section.........6 feet to

8. Coal, containing several thin clay streaks and partings, which seem to be persistent along the whole face of the wall. The coal is very regular, having suffered little distortion. The dip is $\mathbf{2 5}$ degrees E. N. E.....

9. Clay and coal, the latter midway and 8 inches thlck; the clay is light colored and has thin flms of coal. .

10. Coal, with two clay partings apparently persistent and varylng from 1 to 3 inches; they carry some Iron-

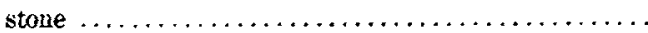

11. Clay, persistent along the whole face............

12. Coal, with four partings, all very thtn except when Ironstone is present; balls of iron-stone are common in the coal, which is always distorted around them....

13. Ironstone, persistent................. Inch to

14. Coal $\ldots \ldots \ldots \ldots \ldots \ldots \ldots \ldots \ldots \ldots \ldots \ldots \ldots \ldots \ldots \ldots \ldots \ldots$

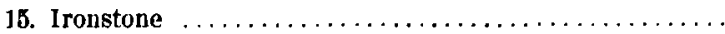

18. Coal with persistent thin elay parting midway.......

The beds, Nos. 8 to 16 inclusive, may be takei as a single mass, 28 feet thick.

17. Coal and elay shale; 4 bands of coal, 4 to 19 Inches, and 4 of clas, 4 to 10 inches; all showlng great variation in thickness. Thin streaks of coal are in

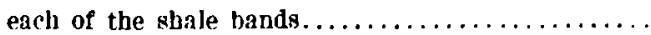

18. Clay sbale, irregularly bedded, somewhat distorter, has a 2 to 8 toch coal layer and several thinner streaks..

Feet Inches

\section{0}

This mass is a notable feature on the opposite wall.

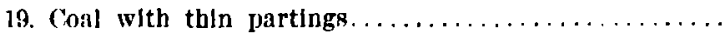

20. Shale with ironstone...............2 inches to

21. ('inl with midway a bony parting of 2 to 8 inches.....

22. Clay, perststent, irregular, contatns a lens of coal.....

23. Coal

24. Shale, dark, argillaceous...........6 inches to

25. Sandstone, coarse, feldspatbic; hardly coarse enough to be conglomerate, as no fragments larger than a per were seen. The thickness is uncertain as this rock, showu only midway in the decouverte, is folded closely; 3 sexposed in a plt it seems to be not less than

Vios. 23 and 24 fold over the sandstnne.

Ignoring the layers abnve No. 6, the bed, known here as the Paleyrets, is about 70 feet thick: the coal on this easterly side is very regular in bedding and shows few traces of disturbance: in that respect it is greatly in 
contrast with conditions to be described in the Bourran bed; and it is unexpected, for on the western side of this découverte, one finds the most complicated of the folds in this basin.

The conglomerate, overlying the coal in some places but separated from it by clay shale at others, is recognizable at once as that belonging in the Campagnac system. In ascending order. the suecession at Tramont is

1. Conglomerute. light gray: jebbles vary from grains to 10 Feet fnches, ordinarily not more than 3 linches, though those of 4 inches are abundant; white quartz. microgranulite, white mica schlst and gnetss are the rocks represented; some large chunks of shale as well as irregular blocks of coal were seen in the lower portion...................

2. Sandstone, somewhat argillaceous, not coarse gralned, a few pebbles, much (ross-bedded; contahins streaks of roal and

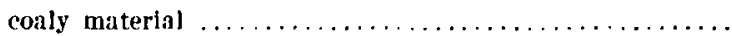

3. Conglomerite. like No. 1, except that the pebbles are not so

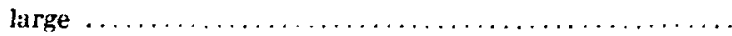

'The dip is eastward like that of an underlying roal: it passes rather abruptly into

4. Sandstone, fine grained and rross-bedded above. where it is markedly argllaceous; the lower portion contalss some pethles, but they are small and not abumint; lenses of coal, 2 to 3 feet long and 2 inches thick. .......8 feet to

5. Massive conglomerates, losely resembling Nos, 1 and 3 , divided by an occastonal shaly hed

Still higher beds are here, but they were not measured. Fidently there is a succession of mostly coarsi' ('onglomerate for more than 150 feet ahove the Paleyrets bed. Some petty faults were scen in the eastern wall near the line of measurement, but the largest is barelv 10 feet. The whole series, coal and conglomerate, has the same dip; but the contant between the conglomerate and the upjor parts of the coal hed showe notable uncomformability of erosion. At times, everything has been removed down to No. 6; occasionally the upper portion of $\mathrm{No}$. 2 was lifted like a flap and the mass of pebbles thrust in under it as a wedge. At several places, the top coal is bent down under the conglomerate, the laminz following rudely the contact between "oal and conglomerate: at some other places the upper layers of the sectinn were shoved into irregular folds and conglomerate occupies the synclinals. It is prident that the passage from coal making to deposition of conglomerate was very abrupt and that the (oal, though perhaps well arvaned in transformation, was still imperfertly consolidated.

In the western wall, the coal and the accompanying rocks have heen pushed into an exceedingly "lose double fold. This begins at a little dis- 
tance north from the decouverte and increases very rapidly toward the southeast. At the bottom of the western wall, the sandstone, No. 25, rises barely 5 feet above the floor of the excavation; at 120 feet southward, it is $\mathbf{1 5}$ and at an equal distance farther it is 25 feet above the floor. The fold continues to increase; in the western wall the top of the coal is reached on the sixth bench, whereas on the eastern wall the coal rises to the tenth bench and the crest has not been reached. Apparently the fold extends southwardly to the Firmy fault. The full extent of the disturbance is not shown in the découverte wall, for the folding is conspicuous beyond on the way down the hill. The anticlinal evidently consists of not less than three close folds in a width of not more than 350 feet. The coal is removed in benches, each about 13 feet high.

That the fold is at least double is apparent at once in the first bench: the disturbance is less on the northeasterly side and there the succession is regular. The same condition is found on the second bench, where the partings of No. 6 are undisturbed, though the coal has been pressed into laminæ, usually almost vertical to the bedding, but sometimes distinctly curved. The mass, Nos. 8 to 16 , being somewhat nearer to the axis, is more affected, some portions being finely polished. On the third bench the coals on the easterly side are often polished like a mirror. On the westerly side the coal is cut off by a fold in the shales, but farther on both coal and shales reappear. This coal comes up thick from the second bench, but in the folding it was cut out by the conglomerate, which comes down from the fourth bench.

In this fourth bench the conglomerate describes two petty folds and then turns almost vertically alongside of the coal. Though folded with the coal, the conglomerate is not conformable with it, for almost 20 feet of the coal is missing. The relations seem to suggest that when the conglomerate was deposited, the coal was torn away; indeed, one is almost justified in conceiving that here is cut the course of a streamlet loaded with pebbles, for at a few feet from the abrupt change in dip, conglomerate is seen resting on the edges of the coal and shale. Above the conglomerate is a mass of more or less argillaceous, crossbedded rock, Nos. 2,3 and 4 of the overlying section, apparently much thicker than in the eastern wall, for it reaches to the top of the fifth bench. In crossing the axis here, twn folds are seen, but the coal is still quite regular on the easterly side.

On the fifth bench, on the westerly side, the shaly beds of the conglomerate seem to follow the folding of the underlying conglomerate, but exposures on the bench above indicate that the apparently increased thickness is due to a squeeze and that the more yielding rock has been pressed 
into a pocket between the two rigid conglomerates. On this bench, the double fold becomes more intricate, for the westerly wrinkle has been pushed past the vertical, the conglomerate underlies the coal, while the shaly mass above the conglomerate shares in the fold. $0 n$ the easterly side, the conglomerate rests on the eroded surface of No. 6, but at a few feet away it has the same dip as Nos. 8 to 16 , which underlie the badly crushed and contorted mass, No. 7 .

The highest exposure of the coal is on the sixth bench, where it is overlain by shale. The coal rises to not more than three feet above the floor of this bench. Thirty feet away on the easterly side the conglomerate is at the floor; at the crest of the fold, it is 10 or 12 feet; at 25 feet away toward the southwest it is again at the floor. But in the latter interval it describes an extremely close fold; the two conglomerates are almost in contact; the shaly mass has been so squeezed that barely one foot of shale separates the conglomerates, the rest being in the pocket seen on the lower bench. This shale has laminæ of carbonaceous matter, which pass down vertically alongside of the conglomerate, in which the pebbles have their longer axis almost vertical.

The distortion of the conglomerate is most marked on the 8outhwesterly side of the fold, the dip being quite regular on the opposite side. The severe effect of the crush was expended on the coal and the shaly beds above the first conglomerate, which moved between the massive beds above and below, giving local faulting in the coal and local crumpling in the shales. Higher up on the hillside, where one reaches the thicker conglomerates, evidence of extreme distortion is wholly wanting, and the dips throughout are comparatively regular.

The easterly outcrop of the Campagnac-Paleyrets coal bed has been followed northwardly beyond Riou Mort to the Lot River at the north end of the basin. The Grande Faille de Bagnaud evidently crosses Riou Mort just west from Decazeville, for the conglomerates of the Campagnac system are reached at little more than 50 rods north from that stream; but no trace of them appears in the hills west from Decazeville, where apparently all of the deposits belong to the Bourran or highest system.

The Campagnac conglomerates appear rather abruptly on the road leading northward from Decazeville to Levinhac by way of the hamlet of les Estaques, and they remain in sight almost continuously until one passes beyond the Bouquies mine near the river. Those conglomerates, in beds 6 to 20 feet thick, alternate with fine grained sandstones and argillaceous shales, 8 to 10 feet thick, showing alternations of torrential and moderate flow in the stream which supplied the material. The pebbles, often fattened in shape, are one to three inches long, but many of them 
have a longer diameter of six inches. The difference in form as well as in the composition of the pebbles enabled Bergeron, Jardel and Picandet to determine that the stream giving this deposit entered the basin at the northeast near the Pont de Bourran. The dip of these beds, though slightly interrupted at times, is southwestward or south of west at not far from 30 degrees, until one passes the summit at les Estaques, somewhat more than a mile north from Decazeville.

At barely 750 feet from the fork in the road at les Estaques, a conglomerate is shown dipping south of west at 30 degrees; but there the dip is reversed to north of east. At 300 yards farther the southwestward dip is resumed, and it is retained until one is directly above the entrance to the Bouquies mine. There a deep side cut shows a sharp fold with steeper dips on the northeasterly side, the beds being almost vertical; but this decreases to 20 degrees within a few rods, and that rate continues as far as the beds were followed. The exposure at this place shows between sandy and conglomerate beds, a mass of shale almost 25 feet thick and containing some thin streaks of coal. No other trace of carbonaceous material was observed at any exposure along this line; this exposure is more than 200 feet above the Bouquies mine. No closer determination was made, as atmospheric conditions rendered the aneroid useless. The coal at this mine was not measured; it is reported as being 48 feet thick.

The Campagnac deposits show only slight differences in type, and such as are shown are due mostly to the sources whence the materials were derived. They were made by streams from the southeast and northeast, and the physical structure of the deposits shows that practically similar conditions of flow existed contemporaneously on all. The thickness of the Campagnac system varies. $\Lambda$ cross section constructed by SaintMartin of the Campagnac company seems to make the interval between the Campagnac and Bourran coal beds not far from 175 meters at the bottom of the syncline west from Cransac. But A. Jardel, director of the Decazeville company's mines, states that in the Puits de Decazes, near Cransac, he reached the Campagnac coal at about 200 meters below the surface, and he is inclined to think that the interval between the beds is nearly 300 meters, the dip of 27 to 30 degrees being ignored. It is wholly probable that each determination is correct for its locality and that the interval between the beds decreases toward the west. A trial pit was aunk below the Bourran coal bed near Decazeville, but the test was not continued directly; at the bottom of the pit a horizontal entry was driven in the direction of the dip and a new pit was sunk at its end near the bottom of the syncline. It is difficult to determine accurately the relation of the two pits to the Bourran bed, but beyond doubt the test was carried to approximately 1000 feet without reaching the Campagnac 
bed. In this the dip of at least 30 degrees is ignored. Apparently, the interval between the coal beds is between 750 and 800 feet along the middle line of the basin and decreases toward the west.

A stream entering at the southwest near Valzergues is believed by Bergeron, Jardel and Picandet to have begun its work during the Campagnac period. They refer to the agency of this stream an isolated area of granite conglomerate south from Valzergues, covering about 30 hectares and resting on mica schist. It consists of granite blocks, four to five meters in diameter, with rounded angles, and the intervals are filled with granitic sand rich in feldspar. They think that the great size of the blocks proves that they had been carried only a short distance. Farther north is a conglomerate of mica schist and granite, also resting on mica schist and succeeded by sandstones and shales containing some thin coal beds, which are thought to be older than the Bourran system.

The Bourran system of Bergeron.- Prior to the close of the Campagnac system, streams bringing noteworthy loads of detritus came almost wholly from the south and the northeast, as proved by fragments inclosed in the deposits. The outlet of the basin is supposed by Bergeron, Jardel and Picandet to have been near Firmy, where those observers found a commingling of materials from the north and the south. There is every reason to accept this conclusion as correct. During the long period of the Auzits and Campagnac systems, the western part of the basin received little material, for except in the extreme southwest corner, there is hardly anything on that side which can be recognized as certainly older than the Bourran. The Lugan and Valzergues seem to have been important during the formation of the earlier Bourran deposits; and another, entering from the west near the present Moulin du Faux, is supposed to have become efficient at the beginning of the Bourran.

The earliest deposit, as described by Bergeron, Jardel and Picandet, is a conglomerate formed everywhere of enormous granite blocks, whose "colossal dimensions" are seen as one gors from the Riou Vieux up to the hamlet of Faux. Some of them measure "10 metres cubes." The intervals are filled with granitic and, and hlocks of granulite are seen occasionally. This "granite conglnmerate" is followed readily southward for three miles, to near Montbazens, the blocks becoming smaller, though still of great size. An insignificant outlier remains north from Faux on the granite itself. The "granite conglomerate" is succeeded by a mica schist-micrngranulite renglomerate, derived in chief part from the south: and this in turn is succeeded by sandstones and shales with some coal beds, most of which are ton thin to repay working. This whole series is referred by its describers to the Bourran avstem. Its rocks were not examined by the writer. 
In descending the Enne valley from Cransac to Viviez, one finds only few and isolated exposures along both the railroad and the wagon road. For the most part the sandstones, as shown, are not very coarse. The coal of the Bourran system is cut by the stream, but the thin beds, being without economic importance at present, are not mined, and no trace of them was observed along the roads. At a very little distance from Aubin, one passes abruptly from Coal Measures to gneiss and to granite as by a fault. This granite must be largely of the type which yields readily to weathering, as the topography is almost as rounded as that in the basin.

From Viviez to Decazeville along Riou Mort, the conditions are unlike those observed in the Enne valley. At Viviez, one is in the mica schists, which are less vielding than the granite west from Aubin. The Riou Mort valley passes abruptly from the bold angular hills of schist to the rounded hills of the Coal Measures. But before reaching the latter, one crosses a narrow prong of microgranulite, which intervenes between the schist and the Coal Measures. 'The contact with the latter rocks is not shown at road level on either side of the valley, but on the northerly side the concealed space is very small, and one comes quickly to a great conglomerate with the pebbles all rounded and frequently six inches in diameter. The exposures begin opposite the pottery at Laboudie and continue to within half a mile of Decazeville, the higher beds being less coarse and containing much shale as well as fine-grained sandstone.

On the southern side, everything is concealed beyond the microgranulite exposure for almost half a mile by a thick deposit of stream clay, used in the pottery. Beyond that the conglomerate is shown, containing pebbles of white quartz, white mica schist, some of gneiss and very many of microgranulite. These pebbles are smaller than those geen on the northern side and are from one to three inches in diameter. The source of the material is from the direction of Viviez, as suggested by Bergeron, Jardel and Picandet. At about 200 yards farther, as one reaches the outskirts of Decazeville, an imperfect exposure at the roadside shows higher rocks for 100 feet,

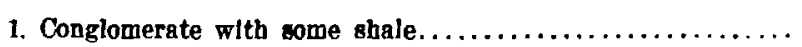
Feet The pebbles are one fourth of an Inch to one Inch; there are very few of white quartz, whlte mlea schlst and gnelsi prevall ; none of mlcrogranulite was seen.

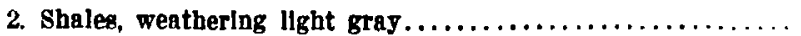
Contaln pockets of coal 2 to 3 fnches thick; the shales are contorted and the coal pockets may be tragments of a contInuous bed.

3. Shales and shaly sandstonfs....................

The dip of $\mathrm{N}_{0} .3$ is eastward at about 25 degrees. 
All of the beds along this line are to be taker as belonging to the Bourran system and the Bourran coal bed extends northward beyond Riou Mort to be known as the Couche de Saint-Roch. It is continuous almost to the north end of the basin, but, though retaining considerable thickness, it contains much shale, and, owing to the proximity of the great deposits of both Campagnac and Bourran systems, its economic importance at present is very small.

At Decazeville, one reaches the area in which the Bourran bed has its great development. The Bourran coal bed has escaped erosion at only one locality in the eastern portion of the basin, where a small area remained, south from the Firmy fault. The coal has been mined there for much more than a century, but mining operations are almost at an end, as the workings have reached the village under which the bed passes. The decouverte is about 2 kilometers long by one fourth to one half kilometer wide, and the coal has been removed to be replaced by waste from the iron and steel works at Decazeville. As now exposed, the coal at Firmy is compressed into a very close fold, whose axis passes directly under the Firmy church. Only a small part of the bed is shown, as rubbish covers the slope on both sides of the exposure. The dips are abrupt, 50 to 60 degrees on the northwesterly side, but so crumpled and distorted on the opposite side that no determination can be made. Exposures on the road to Auzits show that the fold is double.

The company's engineers give the thickness of the coal as about 50 feet. Blavier, as cited by Bergeron. gave the visible thickness in 1906 as 70 meters, and he believed that the mass exceeded 100 meters. This exaggerated estimate was due to the fact that the workings at that time exposed the face of the double fold. The dips become comparatively gentle at a little way from the fold, so that winning of the coal by dix'ouverte was a simple and not expensive method, the amount of rover to be removed being comparatively small. In this découverte, one ohserves the unfortunate tendency of the Bourran coal to spontaneous combustion, which has led to loss of vast quantities of coal in the several découvertes. The ignited mass gives ashes at the surface, coke lower down and still lower a beautiful anthrarite with no apparent trace of porosity or weakness of structure. This charred coal cannot be utilizeri by the company, as a very small proportion ruins the coke, but it is employed in manufacture of brick and in some other industries.

Passing over to the principal area of the Bourran, one finds the coal with only moderate thickness toward the southern border: and no mines are in operation south from Cransac, because the thicker deposits are arailable at the north. The bed forms a syncline, cropping out again at 
the west as it approaches the line of eriptive rocks. It is said to be thinner and less pure toward the west, where it breaks up into several benches separated by considerable shale partings. Openings, no longer in operation, were seen along the eastern outcrop south from Cransac, where the extreme thickness reported is 18 feet. At Cransac, one is barely 1,000 feet from the great découverte of the Sociéte des Acieries de France. The outcrop of the coal in this space is represented by an oval on the map and the deposit is known as the Couche de Fraysse; but the coal is continuous from Cransac to Decazeville and the interrupted outcrop indicates only erosion where the anticline is crossed by the Ruisseau de Banel.

Note has been made of a serious disturbance in the beds near Cransac. If one go north-northwest from that city and climb the hill, following a path passing an abandoned opening in the Bourran and crossing the summit near the old house known as la Montet, he sees, in the rolling space beyond, the Fraysse découverte, which occupies a space of fully half a square mile. A broad complex fold has kept the coal near the surface and made it so readily accessible throughout the space that now comparatively little remains. The present workings on the east side were not visited; the thickness varies from 15 to 20 meters. A vast quantity of coal has been lost by spontaneous combustion, and one portion of the area is known as "les Estuves."

Going northward along the ridge with the old workings constantly in sight at the east, one soon reaches an abandoned découverte, in which the laminated sandy shales overlying the Bourran coal are dipping sharply toward the west; but within a few rods an anticline is reached and the same beds have eastward dip of 35 degrees. At the La GuaCombes road, a quarter of a mile beyond, the lower portion of the bed describes two close folds. West from this point as the road descends toward La Gua, the coal and its overlying laminated sandy shales are shown with sharp westward dip, while the upper part of the bed is high up in the hill overlooking the summit of the road. At this summit, one looks northward to the Banel, erosion having removed most of the coal bed along the axial line.

The fold diminishes northwardly with great speed. At the road summit, only the lowest part of the bed is shown, the greater portion being in the hill at the west. Descending thence towards the découverte Domergue, belonging to the Iecazeville company, one sees the coal outcrop dropping in the hill at the west, while the middle lines of the fold are distinct in the declining hill followed by the steep rond. At the Domergue, almost 300 feet below the summit of the La Gua road, the 
coal is under the surface on the western side and its overlying laminated shales are shown in the bluff behind the machine house, a northward fall of fully 500 feet in less than half a mile. The coal is traceable directly from the Fraysse to the Domergue decouverte and the lower portions have been mined at several places along the hill descending to the Banel.

The dip of the coal is sharply westward on the hillside facing the Enne valley. A serious and somewhat complicated fault exists between the Fraysse area and the hill west from Cransac, where one finds the outcropping Couche du Crol, the same bed. This fault apparently decreases toward the north.

The sextion above the coal in Domergue decouverte is

1. Sandstone, more or less conglomeratic, in thtck beds, xllf, xIl. 60

2. Sandstone and shale, $x f 1 \ldots \ldots \ldots \ldots \ldots \ldots \ldots \ldots \ldots \ldots \ldots$

3. Shale, light colored, $x 1 \ldots \ldots \ldots \ldots \ldots \ldots \ldots \ldots \ldots \ldots \ldots$

4. Shale, dark with tronstone, $x i \ldots \ldots \ldots \ldots \ldots \ldots \ldots \ldots \ldots . \ldots \ldots$

5. Shale, fisslle, blutsh gray, $x 1 \ldots \ldots \ldots \ldots \ldots \ldots \ldots \ldots \ldots \ldots .20$

6. Sandstone and shale, the sandstone in part laminated and (ross bedded, $x i, x \ldots \ldots \ldots \ldots \ldots \ldots \ldots \ldots \ldots \ldots \ldots, 12$

7. Shales weathering dark, $x, 1 x$, vlil................ 40

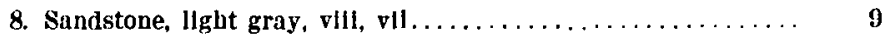

9. Shales, 4 feet to vill, vil. ..................... 20

10. Sandstone, light gray, fine gralned, vil, vi........... 8

11. Shales and sandstones, laminated throughout; thickness cannot be determined exactly from the exposures; is very undulating on the benches; extremely flexed at west end of decouverte; appears to rest directly on the coal south from the La Gua road; thickness not far from............. 50

So that the interval from the coal to the first of the conglomerates sandstones is approximately 170 feet, filled mostly with argillaceous shale. No trace of coal was seen anywhere in this interval or in the sandstones above, of which only 60 feet were measured. The exposure is complete throughout. The coal is mined by shaft on the east side of the découverte. The removal of material in the open work is by benches and the Roman numbers in the table indicate the benches on which the exposures occur.

This découverte cuts the axis of the Cransac-La Montet anticline, but exposures are very poor below the fifth bench. In great part, the exposed coal has been destroyed by spontaneous combustion, and fire is still at work; the hill is known as the "volcano," for clouds of smoke rise from many fissures. The coal, below the surface on both sides, rises midway to the seventh bench, about 150 feet below the summit on the La Gua road, where only the lowest part of the bed is shown. 
On the fifth, sixth and seventh benches, the coal is thrown into complex folds, which are faulted, for on the seventh, the sandstone, No. 8, is at only three or four feet above the coal, from which it is separated by shale, rolled into flakes like pastry. The shales, No. 7, are closely plicated as they pass over the folds, but all complexity ends with the sandstone, No. 6, which shows, as the only trace, a crumpling of the thin inclosed shales. The higher beds are regular. The faulting and sharp folding end with No. 6 ; the effects of the lateral pressure were expended on the yielding lower rocks, which slipped and bent sharply or were faulted locally, while the hard upper rocks made simply a broad fold, the conditions in this narrow anticline being precisely those observed in disturbed regions of great extent, where some beds are faulted, crumpled or pushed into pockets, while other and more massive inclosing beds seem to be little affected by the disturbance.

The fold is very narrow. Climbing out of the découverte at the eleventh bench on the eastern side, one finds the easterly dip already gone, the beds on the twelfth and thirteenth benches show westerly dip of 25 to 30 degrees, and this dip prevails to the supposed line of the Bagnaud fault, only a few rods farther east. Just outside of the découverte is the road from Decazeville to Combes; following that to the summit, one sees fumes issuing from many fissures, while farther west on the hillside is the outcrop in an old découverte, marked by a broad epace of white, whence dense fumes arise constantly. Here one looks down on the ventilating shaft of the Bourran mine, now used for removal of waste and the blackband which in that mine covers the coal bed. The coal crops out in the steep road just below an abandoned dwelling, where it is exposed for several rods. The dip is such that, if continued. it would carry the coal far above the Tramont découverte, barely one fourth of a mile away at the east; but it is interrupted, for Bergeron, Jardel and Picandet have recognized the Bagnaud fault in the interval.

The Bourran shaft is reached at somewhat more than half a mile from the Domergue. The coal, 40 meters below the surface, is said to be 45 meters thick. At the Domergue, the thickness is giren as 60 meters, the dip being ignored. At the Domergue, the dip where last seen at the east is 40 degrees eastward ; near Bourran, the surface rocks dip between 25 and 30 degrees.

The great découverte of Decazeville is only 700 feet north from the Bourran shaft. Like the découvertes already mentioned, it was begun along the crest of a close fold and the old workings were confined to a narrow space on each side of the anticline, where that was at nearly the maximum. The great excavation is farther north and reaches better coal, as this fold, like the nthers, decreases toward the north very rapidly. 
The coal in the newer portion is 120 meters below the hilltop, and the whole of this cover must be removed. The work of removal is done in benches, each four meters high, and the coal occupies the first eight, midway in the excavation. The disturbance in the coal is such that a definite section cannot be obtained such as that at Tramont; it is impossible to determine even the original thickness of the bed. But the fine exposure on the easterly wall enables one to ascertain the general structure of the bed, while that on the southerly wall exhibits in part the fold. Serious faults are distinct, but the mass of coal reaching to the eighth bench is outside of the main fault and is continuous.

On the eighth and seventh benches, there are eight meters of coal with indefinite partings; whether or not these were persistent in any case cannot be determined, because the coal is crushed by petty faults and irregular folds. A clay parting three inches thick was seen on the sixth bench and was followed for some distance, but it disappears abruptly, as if cut off by a fault. Ironstone concretions are numerous on this bench, and the coal has concentric structure around them. Some partings and pockets of shale were seen on the fifth bench, but they are not in their original position and their relations cannot be determined. $\mathbf{A}$ three-inch bed of clay is shown on the fourth bench, where also are numerous thin clay partings; but most of them have been broken up into small pieces with polished surface. A large mass of ironstone is a notable feature at this exposure. Throughout, the coal has been broken into wedges, large and small, some of the former showing a lens-shaped section. On the third is a streak of hard clay, six inches to one foot thick, evidently persistent, for it crosses a fold on the main floor of the excavation. The coal on this bench, as on those below, is much curled, and faults of two to three feet are numerous.

Here is a face, more than 100 feet high, and containing no certainly persistent parting more than a few inches thick; indeed, to all intents, the mass is continuous coal. Dips of 25 to 40 degrees were observed; one may take 25 degrees as the average without danger of underestimating the mass; the thickness of the bed may be about 90 feet.

But underlying this coal is an argillaceous shale with some sandstone, the top of which is seen in the lowest part of the découverte. It is a striking feature in the southerly wall, where its light color makes cleur the vagaries of the fold. When first encountered in the northerly part of the excavation, this mass was 22 meters thick; but it decreased rapidly, so that in the bottom of the découverte it is only six meters. while in the Bourran shaft, 200 meters away, it has disappeared. Belnw it is roal, more than six meters thick. which is not removed in the open work- 
ings, being reserved for underground working by means of a shaft outside. It is exposed in the southerly wall.

The top of the coal is reached on the eighth bench, where one finds a few feet of the overlying shale; but there is no continuous section above, as at Domergue, for this easterly wall is cut by some important faults, whereby the coal reaches successively higher benches toward the south, before the folded area has been reached. In descending the incline from the thirteenth to the twelfth bench, one crosses a fault which brings the conglomerate sandstone, No. 1 of Domergue, against the laminated beds No. 11 of Domergue, while on the eleventh bench that sandstonc and the coal are almost in contact. This fault appears on the thirteenth, bench at the point of the hill, but it is equally well defined at the northerly end, where exposures reach to the fifteenth bench and the coal. rising eastward, is shown much folded and with only 10 feet of shale between it and the fault. This fault, viewed from the southwest corner is very distinct from the thirteenth bench down into the coal of the ninth. The measurement of the coal already given was made on the easterly side of this fault; at a few yards southeast, the coal reaches to the tenth bench. The other faults are of slight vertical extent.

The interval between the coal and the great sandstone is not fully shown in this wall, owing to the faults, but the beds in contact with the coal resemble those seen in the Fraysse and Domergue workings. The sandstones above are light gray, with many layers of pea to chestnut conglomerate and are not far from 200 feet thick; while near the top of the hill are reddish or reddish brown beds which have been recognized as Permian. When the great disturbance occurred, the massive rocks above broke into huge blocks or were pushed into a broad fold, but the coal and shale, the weaker materials, were crumpled, thrown into multitudinous petty folds and broken by local faults. At the Bourran shaft, one is apparently outside of the faulted area, for there one sees the shales and sandstones to fully 200 feet above the coal, the dip of rather more than 30 degrees being ignored in the measurement. The succession seems to be regular on the westerly side of the Decazeville découverte, where the section resembles that at Domergue, except that two sandstone beds, six to eight feet thick, in the lower part contain streaks of conglomerate with pehbles sometimes one inch in diameter. Several sandy layers show many impressions of plants and of stems, some of them large enough to be regarded as tree trunks.

Standing at the northwest corner of this découverte and looking toward the southeast, one sees in the southerly wall a sharp carinated fold. whose abrupt middle portion is marked by the light-rolored shale 
underlying the main coal. Beyond that is a broad valley, rising rapidly and marking the place of the old découverte, whence the coal was taken prior to the consolidation of the Commentry and Decazeville companies. The direction of these old workings is indicated by a white space covered with ashes and by the fumes which rise in such dense clouds that the hill is known as the "montagne-qui-brule." An immense quantity of coal was removed from this old découverte, where owing to rapid development of the fold the bed was reached with minimum of stripping. But the crush was very great, and the coal must have been much more broken than in the present workings. The systematic methods pursued by the director, M. Antoine Jardel, have led to securing coal much less injured and to reducing very greatly the loss by fire.

The coal in the southerly wall is no longer recognizable above the twelfth bench; but before the great destruction by fire, the face of coal shown along the fold must have been at least 250 feet high and more than 300 feet wide at the bottom, fully deserving the name, "mountain of coal." The bizarre arrangement in the wall, which is not well shown in the defective photograph, is that of the underlying clay; the great coal was exposed on both sides. This clay enables one to recognize the rapidity with which this fold, like the others already mentioned, decreases tnward the north. In the southerly wall, one of the lower clays is squeezed into a carina on the eleventh bench; but, midway in the excavation at the level of the third bench, the highest of the clays folds over the anticline, a fall of 130 feet in barely 300 . The exposures in the wall are very good and illustrate well the manner in which the readily yielding clays were divided and pushed into spaces between blocks of more rigid materials.

The coal is traceable on the twelfth as well as on the eleventh bench. but in great part it has been baked so as to be worthless. A fine exposure on the eleventh consists almost wholly of beautifully compact anthracite with no macroscopic evidence of porosity. This proves that, under proper conditions of pressure, bituminous coal can be converted into anthracite within a brief period by slow distillation alone. On the lower benches, beyond the influence of the fire, there are many illustrations showing the effect of pressure on structure. The shales vary according to composition; the harder, coarser beds have been folded so as to show long curved faces, often along the bedding, while the finer, more argillaceous beds have been squeezed into wrinkles, sometimes vertical to the bedding, sometimes parallel; while in many cases they have been crushed into lenser, polished so as to resemble talcose schist. 
The coal above the shale is distorted seriously only in the lower portion, where the wrinkling is complex on the easterly side, the dips sometimes reaching 70 degrees. The thicker coals on that side, in several places, have lost their original structure and they are now in slabs, one to three inches thick, extending continuously in the wall of two or even three benches. The dips on the opposite side rarely exceed 40 degrees, and the coals above the clay are less affected, but they are folded gently and occasionally show petty faults.

Within the fold of shale, the underlying coal has suffered materially. An accurate measurement of this exposure cannot be given, as the wall is sometimes diagonal to the dip and at others parallel to the strike; the succession descending is

Feet Inches

1. Shale, argllaceous, much contorted............ 10

2. Coal, irregular, much twisted............ foot to $1 \quad \theta$

3. Shale, arglllaceous, drab, follated like schist, has a coal streak midway.................... $8 \quad 0$

4. Coal, many pockets of shale, much tronstone; the shale is argllaceous, Irregular and flaky.............

5. Arglllaceous sbale; this has its carina on the eleventh bench, but forks on the tenth and it is the roof of the underlying coal bed; averages...............

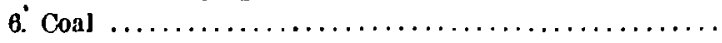

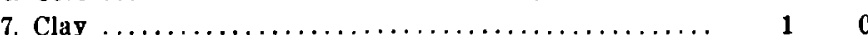

The coals are broken into wedges with polished and often rounded surfaces. Exposures in this wall are complete down to the third bench; as one descends, the effects of the crush become more complex, the coal and shale are broken into large fragments and intermingled, until on the third bench the material seems to be hardly worth removing.

But northwardly, the condition becomes simpler. An exposure at the foot of the incline, on the lerel of the third bench, shows the decreased fold with these beds:

1. Conl. mined on the third bench, where It is wrinkled into a fold, which is distlnct on the fourth and fifth benches.... .

2. Shale, argllaceous, dark, often with an almost cone-ln-cone structure; when blown down, It breaks Into rudely cyllndrical fragments with highly pollshed surface...........

a Coal and shale, rolled into laminge one elghth to one inch thick, with curved and polished surfaces............ o

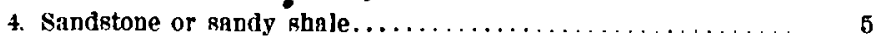

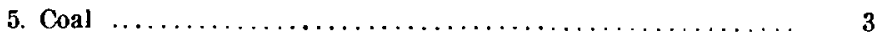

6. Sbale, apparently the upper light colored shale seen In the southern wall; is sharply contorted on the westerly side of 
the fold, the condition being complicated by a small fault, 80 that it has been rubbed into close wrinkles by the vertl-

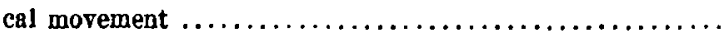

7. Coal and shale, involved in the fault, beyond which it is almost vertical, but its laminæe are curved with concavity

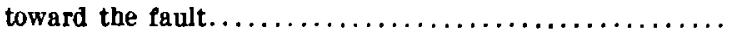

There are few exposures in the hill west from Decazeville. 'The coa: passes under it at the découverte. Just beyond the church square, one sees the Vialarel mine at a short distance above the level of the strect. Around the hollow occupied by the mine buildings as well as along the road leading to a hamlet higher up the hill, are exposures of massive sandstone, with thin beds of shale and with many pebbles, though not enough of them to make a conglomerate. This rock has no resemblance to the conglomerates of the Campagnac system, which are exposed at barely half a mile away toward the north bevond Riou Mort; it resembles rather the sandstones above the Bourran bed. The coal bed reached in this shaft was supposed to be the Campagnac, but a tunnel, driven through from the decouverte, encountered no conglomerate. The bed evidently belongs to the Bourran system and is low down in it, but its precise relation to the great bed is still undetermined. The coal is 15 meters thick and of excellent quality.

\section{CHARACTER OF THE COAL}

The following analyses are by M. Nevron Saint-Julien, chemist of the Decazeville company.

\begin{tabular}{|c|c|c|c|c|}
\hline 1. Bourran ........... & $\begin{array}{c}\text { Vol. mut } \\
\mathbf{3 4}\end{array}$ & $\begin{array}{c}55 \\
55\end{array}$ & $\begin{array}{r}1+h \\
11\end{array}$ & $\begin{array}{c}\text { Fuel ratio } \\
1.6\end{array}$ \\
\hline 2. Fraysse $\ldots \ldots \ldots \ldots$ & 35 & 59 & 6 & 1.67 \\
\hline 3. Domergue $\ldots \ldots \ldots$ & 35 & 51 & 14 & 1.5 \\
\hline 4. Flrmp $\ldots \ldots \ldots \ldots$ & 35 & 57 & 8 & 1.6 \\
\hline 5. Miramont $\ldots \ldots \ldots \ldots$ & 37 & 53 & 10 & 1.44 \\
\hline 6. Vlalarel $\ldots$. & 35 & 52 & 12 & 1.6 \\
\hline 7. Campagnac $\ldots \ldots$ & 32 & 58 & 10 & 1.8 \\
\hline 8. Bouquies $\ldots \ldots \ldots$ & 35 & 57 & 8 & 1.6 \\
\hline$\ldots \ldots \ldots$ & 37 & 56 & 7 & 1.5 \\
\hline$\ldots \ldots \ldots$ & 28.3 & 54.6 & 171 & 1.94 \\
\hline
\end{tabular}

'The analysis in each case is of dry wal, the mulsture not exireding 0.7. Nos. 1 to 6 are from the Bourran bed; from 7 to 9 are from the Campagnac bed; the one analysis from the Soulier bed is that of a hand specimen taken from the old workings, ${ }^{5}$ so that it may not represent

I am indebted for this analysig to $M$. F. Brocard, who collected the specimen and sreured the analybis after my departure. 
fully the composition of the coal. There is notable variation in the several parts of the bed, Nos. 1, 5 and 6 being from contiguous localities. There seems to have been little change as the result of the abrupt folding; hence, a series of analyses showing the composition of the coal in each yard from the bottom to the top ought to prove serviceable to the student busied with the origin of coal; such a series should show variations like those in the Mammoth bed of the Southern Anthracite field. The coals from Miramont, Domergue and Bourran are under cover of the Bourran and Permian deposits; but the coal of Fraysse and Firmy are in localities which must have been freed from most or all of the Permian and perhaps some of the Bourran load during the pre-Jurassic erosion.

At first glance, one might be tempted to draw some conclusions from the relations of the fuel ratios; but several ultimate analyses by $\mathrm{M}$. Neyron Saint-Julien induce hesitation. These show that the composition is unusual for a Carboniferous coal; at all events, it is very unlike that of Carboniferous coals in Great Britain and America. The results are:

\begin{tabular}{|c|c|c|c|}
\hline & Carbon & Hydrogen & oxygen and nitrogen \\
\hline 1. Bourran .... & 63 & 4 & 33 \\
\hline 2. Firmy $\ldots \ldots$ & 70 & 5 & 25 \\
\hline 3. MIramont & 69 & 5 & 26 \\
\hline 4. Rulhe ...... & 70 & 6 & 24 \\
\hline
\end{tabular}

The composition is that of the dry coal in each case. M. Brocard states that a cold solution of caustic potash ordinarily has no effect on the coal, but, most commonly, boiling colors the solution pale yellow to black. This test is employed to determine the coking value of the coal; when the coloration is brown, the coal gives a poorly consolidated coke. This incidental observation by M. Brocard is evidence that material differences in composition exist within the bed. Several years ago, Stevenson" subjected a number of Carboniferous and Cretaceous coals to the caustic potash test and found that those giving a good coke were not attacked even after long boiling, while the open burning were attacked readily. He supposed that he was in the way to discover a convenient mode of determining the value of the coal, but Canadian reports of recent years give numerous instances of coals readily attarked by caustic potash yet yielding strong coke. These coals are closely allied in composition to lignites. The Decazeville coal cokes readily, but the coke is not strong and the burden must not exceed 60 feet.

The peculiarity of the Bourran coal which at once attracts attention is its tendency to spontaneous combustion. A heap more than six feet

- J. J. Stevengov, "Juransle coals of Spltzbergen," Ann. N. Y Acad. Scl., rol. xph p 90, 1895. 
high quickly develops an internal temperature of $60^{\circ} \mathrm{C}$, and, if neglected, ignites within a few days. The zinc company at Viviez, two miles from Decazeville, stored a great quantity of the coal in a heap somewhat more than 8 feet high. The rapidly increasing temperature was discovered just in time to prevent destruction of the mass. The danger is always present at outcrops, new or old. Fifteen jets of smoke were seen at one time on the easterly wall of the Decazeville découverte, where the watch to prevent conflagration is incessant. Everywhere in the great decouvertes the ravages of spontaneous combustion are proved by areas of whitened surface and cindered rocks. Some of the underground workings are charged with grisou and miners use only safety lamps. The Campagnac coal has the same tendency, but it is less marked, for an official of the company at Cransac stated that heaps eight feet high are safe. The sulphur in these coals is not excessive, little more than one per cent.

In this connection, it may be well to note that the Campagnac bed is separated at most by two or three yards from the overlying conglomerate beds, open-grained rocks, while the Bourran bed underlies a great thickness of more or less argillaceous deposits, close-grained rocks. If the process of transformation continue to any great extent after burial of the coal material under the inorganic load, the Campagnac coal should show a greater difference from that of the Bourran than is indicated by the analyses; the more so as they are separated by an interval of 750 feet.

The writer's purpose in studying the Decazeville basin was to ascertain whether or not the conditions existing there favored the doctrine that ('oal beds are composed of transported vegetable matter. Any hypothesis nffered to account for formation of the coal beds must take into consideration certain important features of the basin, such as

The original extent and chararter of the basin,

The manner in which the mineral detritus was deposited and the features of the streams which did the work,

The extent and distribution of the coal beds.

1 ertain structural features, such as the folding and faultung being of later origin, have no bearing upon the general question.

THE ORIGINAL EXTENT ANI CHAKACTER OF THE BASIN

The Decazeville Coal Measures occupy a depression in the Archean - hists and are bounded, at least in part, by faults which have no direct wation to those observed within the hasin. 
The limiting fault at the west, recognized by Bergeron ${ }^{7}$ in 1888 , is distinct from the southern border northward, passing on the west side of the granite area, but making an angle at Riou Mort, whence it is traceable to its disappearance under post-Carboniferous rocks at the north. On the eastern side a well-defined fault extends northwardly to beyond Riou Mort, east from Firmy; and the map by Bergeron, Jardel and Picandet makes it very probable that a fault continues from Riou Mort to the northern part of the basin, as was suggested long ago by Bergeron. Whether or not the basin was limited by a fault at the south cannot be determined from the observations now available; but the existence of such a fault seems to be more than probable. Bergeron's sketch-map marked it as extending from the western boundary near Valzergues southeastward to the mica schists on the opposite side, but the map in the later memoir does not show it, as its place along the greater part of the southern border is concealed by Jurassic beds. The basin owes its origin to these limiting faults, along which as lines of weakness those adjustments were made which, by changing the relative levels, made possible the deposition of a thick mass of Coal Measures. They may have been involved in the final changes, causing the present complicated structure, but their share in them was merely subordinate. The Permian on the ridge road above Auzits appears to be affected very slightly by the limiting fault.

The area of deposit was confined at first almost wholly to the southeast corner, but it expanded gradually until, at the close of the Campagnac period, it embraced almost the whole of the eastern half and a considerable space along the southern border. During the Bourran, the whole of the present area received deposits. The studies by Bergeron, Jardel and Picandet leave no doubt respecting conditions in the western part of the basin during the Bourran, and the writer adds his testimony in corroboration for localities examined by him. There is no reason whatever to believe that the basin was occupied at any time by a body of deep water; for a long time a great part of the area was exposed to subaërial action. The evidence is positive.

Bergeron, Jardel and Picandet report the occurrence near Antaignargues of a mica-schist breccia, composed of great blocks, which they seem inclined to regard as part of a delta, therefore as deposited by running water. This explanation of the origin is open to question. The vast size of the angular blocks would lead one to think rather of subaërial disintegration as the causal agent. Somewhat similar deposits are described from the southeastern corner. A small area of about eight

'Reunion, efc dans l'Allter. p 82 
acres, south from Valzergues, is covered with a mass of granite blocks with rounded angles, 13 to 16 feet in diameter, and bound together by a granitic sand rich in feldspar. This rests on mica schist and in general character is closely related to a granitic mass at a little distance southeast. Along the western border and extending to the granite area inside of the limiting fault, the earliest deposit is a "granite conglomerate" which can be followed from near Montbazens to the granite north from Rion Vieux. The fragments are of large size even near Montbazens, but they increase northwardly until beyond Riou Vieux, as one approaches the granite, very many of them are " 10 metres cubes" and the intervals are filled with granitic sand, holding blocks of granulite. A small patch of similar conglomerate exists farther north on the granite itself.

When one considers the colossal dimensions of the blocks at these localities, the conception of transport by the insignificant streams entering and traversing the basin becomes at least improbable. The phenomena point rather to atmospheric action: the rounding of the angles in the great blocks west from Montbazens is a commonplace feature of graniteweathering beginning at the joint planes. The writer long ago observed many instances in Colorado, one of which he placed on record. ${ }^{8}$ But it is unnecessary to go far from Decazeville to find a deposit like the "granite conglomerate." Along the railroad from Bort to Aurillac and thence to Capdenac, one sees at many places a thick deposit of granitic sand holding great rounded and angular blorks of granite. At Viescamp-sousJalles, near Aurillac, this is well exposed in a long cut, and it covers the hillsides for a considerable distance eouthward toward Capdenac. Where this readily disintegrating granite prevails, the valley widens, but beyond in the schist it narrows. The granite area within the Decazeville basin must he largely of the readily disintegrating type, for its topography is hardly more abrupt than that of the Coal Measures.

The presence of these conglomerates, the absence of deposits earlier than Bourran in the western portion of the basin and the resemblance to dejection cones shown by the earliest deposits in the southeast corner, all indicate that for a long period much of the basin was dry land, that the water encroached very elowly and that the entire area was not anbmerged or water-soaked prior to deposition of the Bourran system. The isolated conglomerate south from Valzergues cannot be regarded as affecting the question of the original extent of the barin : and it appears to be altogether probable that Bergernn, in his original paper. defined the limits of the depression as nearly as possible. The width can have auffered very

'T. S. Geogr. Expl. W. of looth Mrr wi III ". 348. 1876 
little contraction by lateral pressure; the folding and faulting of the beds may be due to a different cause. Apparently, the only difference between present and original limits is due to the slight transgression of Jurassic at the south and of andesite at the north.

\section{MODE IN WHICH THE BABIN WAS FILLED}

More than 20 years ago, Bergeron recognized in the Decazeville basin all the features required by Fayol's doctrine of delta formations. Deltas deposited in a body of deep water are subaqueous cones of dejection, whose characteristics have been discussed elaborately from the mathematical viewpoint by Lemière. Bergeron saw evidence of three such deltas, two at the southern end and one at the northeast. Twelve years later, when the careful studies, initiated under Fayol's direction and conducted according to the method employed at Commentry, had led to a great accumulation of facts, Bergeron, Jardel and Picandet were able to prove by the included fragments the existence of at least four depositing streams along the southern border, of one at the northeast and the probable existence of two on the western border. Their observations have been referred to incidentally in preceding pages, but they must bo summarized here. They show the value of patient study in what too many think petty matters, for the results are farther-reaching than appears at first glance. The writer desires to pay tribute to those students, whose accuracy of observation and acuteness of discrimination provoked admiration at more than one locality.

Three streams coöperated in forming the early deposits at the southeast corner of the depression, one passing near Longuefort and entering near Iuzits after having crossed microgranulite and mica schist; a second at less than a mile westward, entering near Haute Serre, and a third entering near Lugan. The especial deposit of each is characteristic and the confluence of the cones is well marked. The course of the Haute Serre, the most important of the brooks, is made distinct by the distribution of coarse fragments for a considerable distance northward. A fourth ctream, entering at the southwest near Valzergues, contributed its share somewhat later in the history, while a fifth, entering at the northeast near the Pont du Bourran, gave the deposits marking that portion of the basin. All of these were active during the deposition of the Campagnac system, and the inflowing waters found exit on the east side near Firmy, where elements from north and south are commingled. The western streams, those entering near the Moulin du Faux and from Viviez, gave $\mathrm{n} n$ deposits in the western part of the depression until the beginning of 
the Bourran, when they coöperated with the Valzergues and possibly with the Lagan in filling up that side of the basin.

The studies by Bergeron, Jardel and Picandet have shown that each of these streams was short, especially those entering along the southern border. Those students make no reference to this matter, but the facts recorded by them leave room for no other conclusion. The LonguefortAuzits stream as well as the Haute Serre could have cut back their valleys barely three miles into the ancient rocks, even so late as the end of the Auzits system. The same is equally clear respecting the Lugan; for the massive conglomerate above the Soulier coal bed consists almost wholly of microgranulite pebbles, so that by that time the stream headed in the microgranulite area, the Auzits brook had cut back across the schists to the other area of microgranulite, for its deposit shows mingling of the two rocks. In the case of each one of the three streams, the source of the fragments is open to no doubt. The streams were longer during deposition of the Campagnac beds, though even then the character of the materials shows little change; possibly there was a rehandling of the older beds. Studies of deposits made by the other streams lead to similar conclusions, so that up to the close of the Campagnac, one has to do only with streams of insignificant extent outside of the basin and which in no case could have had an additional length of more than four miles within the basin.

The matter is somewhat less clear on the western side, where, except in the southwest, no deposit was made prior to the Bourran and the conditions already described indicate dry lands during the Auzits and Campagnac. The streams recognized by Bergeron, Jardel and Picandet may have been in existence throughout the whole period, carrying their load nver to the eastern side of the basin, comparatively gentle streams contributing largely to the finer deposits separating the Campagnac conglomerates. But certainly at the beginning of the Bourran, these streams became rapid, bringing in large pebbles, which were dropped abruptly on the border of the basin. while the finer materials were carried farther eastward.

The suggestion that the Vivie\% and Moulin du Fanx streams were already old at the beginning of the Bourran seems all the more probable, when one compares the conditions above the Campagnac coal bed with those above the Bourran. At times, the Campagnac bed passes upward through the ordinary changes of coal and shale to the coarser rocks above, while at others, the passage to coarse conglomerate is abropt, with evidence of erosion during deposit of the first lavers of the overlying rock. Everywhere, the interval from coal to the mass of conglomerate is short, 
represented at most by a few feet. But the interval between the Bourran coal and the coarse rocks above is great, nowhere less than 150 feet, filled with shale and mostly fine-grained sandstone, while the overlying coarser sandstones are only finely conglomeratic, as though composed of older deposits worked over.

Evidence derived from the character of the transported material leaves no room for doubt that the streams were short. The quantity of material transported by them leads to equally positive conclusions. The extreme thickness of the Auzits system approximates 1800 feet, but this measurement is made along the supposed line of the Haute Serre stream. The basal deposit, with an extreme thickness of 600 feet, is very coarse, its fragments are subangular and the exposed area is somewhat less than two square miles. The general character suggests that the material is very near its original source and that it is largely of subaërial origin. It must decrease very rapidly in all directions, especially toward the north, and the Soulier coal bed, if it exist, should be very near the Archean beyond Riou Vieux. The Auzits area increased with the newer beds, so that at the close, its deposits must have covered the eastern half of the depression. One seems to be justified in assigning to this system an area of six square miles with an average thickness of 1000 feet and a content of somewhat more than a cubic mile. For this considerable mass, one must lonk in great part to the three streams at the south, since the exposed area is in their region and the recognized materials could have come only from rocks cut by them. If those streams by the end of the Auzits had dug valleys such as one sees in the upper reaches of the Enne or Riou Vieux, the removed material would suffice for the whole deposit. The Campagnac system covered the eastern half of the basin, not less than 15 square miles in area, with an average thickness of say 600 feet. The content would be somewhat less than two cubic miles, to which all streams contributed. The Bourran system covered apparently the whole area, 30 square miles, with a thickness of say 450 feet and a content of two and one half cubic miles, to which all streams contributed, not only those whose work has been recognized, but also others of less importance.

These estimates may be open to charge of exaggeration, but they have been made liberally. A calculation of cubical content of the deposits suffices to make wholly clear that the whole work of removal and distribntion could have been done by streams, gradually lengthening and deepening their ways until at the close of the Coal Measures the streams and valleys in the schists resembled in size and extent those now existing in the Decazeville hasin. 
EXTENT OF THE COAL BEDS

Little can be said respecting the original or even the present extent of the Soulier-Abiracs coal bed; the outcrop marked on the map encloses an area considerably less than two square miles, from most of which erosion may have removed the bed. How far the coal extends northward and westward under the Campagnac system has not been ascertained, as the matter has no economic importance and no explorations have been made. The greatest thickness is west from the supposed line of the Haute Serre stream, where there is about 10 feet of coal; the total amount inust be large, as the bed goes under cover with undiminished thickness.

It is less difficult to determine approximately the extent and distribution of the great Campagnac-Paleyrets-Bouquies coal at the base of the Campagnac system. That bed is practically continuous along the outcrop indicated on the map, though it is said to be lens-shaped at some loralities. How far it extends toward the west has not been ascertained in the northern part of the basin; an exploratory pit in the Bourran mine did not reach it, having been stopped hefore coming to its place ; but near Cransac the underground workings of the Compagnie des Mines de Cransac have been pushed beyond the outcrop of the Couche de Crol, the Bourran coal bed. This is clear from all the cross-sections constructed by Saint-Martin, in which the bed showa only the ordinary variations, thinning toward some of the faults, thickening towards others. This bed has been recognized definitely nowhere wert from a line connecting Levinhac at the north with Lugan at the south, but there seem to be good reasons for referring to approximately the same horizon some thin and irregular deposits in the southwest corner. The bed, practically single at the south as the Couche de Rulhe, divides near Riou Vieux, the intervals between the lower benches increasing northwardly in the Firmy region, so that in going by the wagon road from Firmy to Cransac, one "'rosses the whole series from the main bed down. The dips throughont are conformable in the Campagnac system and conformable also to the underlying Auzits. There is every reason to believe that the Campagnac coal covered much of the region south from Rinu Vieux, that it underlies the Firmy area and that northward from that area it extended to the eastern border. The conditions observed along the comparatively narrow valley of Riou Mort show that the bed has been removed by erosion there. The presence of Permian in the interior of the basin and its ennformability to the Bourran system seems to be a final argument. Permian is present along the eastern border and along the middle of the basin, but is lacking in the intervening space. Its absence is evidence of great erosion 
by which not only the Permian, but also the underlying deposits, were removed from the southeastern and eastern portions. The relations of the strata throughout indicate that all of the beds, mineral and organic alike, had at one time a much greater extent than now. One cannot be far wrong in estimating the original extent of the Campagnac coal bed as at least 12 square miles, almost all of it on the eastern side of the basin. The thickness of the coal varies, but one is safe in taking it as 35 feet, that being the least reported in any locality where work has been done in recent years and from one half to one third of that observed or reported in localities where work is now in process. Almost the whole of the eastern half of the basin was covered by a coal bed from 10 to 90 feet thick and averaging not far from 35 feet.

The extent of the Bourran bed was greater. It covered the whole of the eastern area, as is shown by the preservation of the Firmy block as well as by the distribution of Permian beds. The Permian covers the Bourran deposits along the central strip, but the Bourran coal crops out on both sides of that strip. The thickness is greatest in the central portion of the basin, but it is still great on the eastern border at Firmy, while at the extreme south, as at the extreme north, it becomes irregular and, though still thick, is broken by many shale partings. On the western side of the syncline south and west from Cransac, it is much thinner than at the eastern outcrop, while at the south on that side, shale partings increase at the expense of the coal. The thinner, irregular beds in the western part of the hasin are contemporaneous with some part of the great Bourran bed, and it may be that the bed was practically continuous over the whole basin: but owing to the energetic erosion, evidence to support that suggestion cannot be obtained. One can only take the area as approximately 20 square miles, confined to the eastern two thirds of the basin. The minimum thickness reported is 18 feet; from that it ranges up to more than 100 feet, so that one is not in danger of exaggeration, if he regard the area as covered originally by the equivalent of 35 feet of coal.

The section of the Campagnac coal bed, obtained at the Tramont déconverte, closely resembles that of the ordinary bed with underclay and with clay partings throughout; hut no such section of the Bourran bed is available, for in the Decazeville découverte, the coal has been faulted and folded within the bed to fuch an extent that one cannot determin whether or not any of the inclosed clays was continuous, but there iample underclay. No impressions of Stigmaria were seen anywhere, st that neither Lepidodendron nor Sigillaria contributed materially to $f_{01}$ mation of the coal. 
'The sterility of the intervening deposits should not be overlooked. The whole succession above the Bourran coal bed is exposed in the hill between Domergue and Decazeville and no trace of coal was seen anywhere in the section. The interval between the Bourran and the Campagnac is certainly 750 feet along the eastern exposures; the lower portion is shown well at Tramont, fragmentary exposures are numerous along the road from Firmy to Cransac and much of the higher portion is shown north from Decazeville. In this great interval, there are few horizons in which traces of coal occur, and those seem to be local.

In this connection, one must not forget that the series is complete and continuous; that a borehole at Decazeville would pass through the Bourran and Campagnac systems into at least the upper part of the Auzits, seen under the Campagnac coal at a little way east; that the Campagnac rocks continue to the eastern boundary, and that the Campagnac coal bed is far under the Bourran coal bed at the most southerly exposures. In this basin, the roal beds are of independent origin; they do not come together at the border.

ORIRIS OF THE COAJ BBES.

The onls hypothesis thus far presented to aceount for the accumulation of coal beds in this basin is that the vegetable matter was brought In by the streams. Bergeron in lisk announced that the delta theory, newly proposed hy Fayol in his brilliant memoir on Commentry, was fully applicable to Decazeville. Brergern, , ardel and Picandet, in 1900, were more explicit, as they had better knowledge of the conditions. The Soulier-Abiracs coal bed was formed by the Haute Scrre stream; the Campagnac bed was formed at the south by accumulation of regetable matter brought down by the Lugan and Haute Serre, while at the north, the Pont du Bourran stream contributed the needed material; the comparatively unimportant Bourran beds at the west are irregular and indefinite berause of their proximity to the entering currents, the fine vegetable materials being carried farther east, there to accumulate beyond disturbing influence of the streams.

The mode in which the coal necurs within the Decazeville is in notable contrast to that observed in the hasin of Commentry. Accumulation of coal in important quantity began at a comparatively late time in the history of Commentry, and it was confined to two insignificant areas separated by the barren zone of Montassiégé. But at Derazeville thre basin

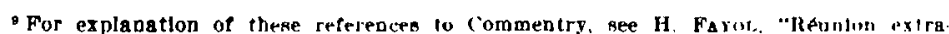
urdinalre dans l'Allter." Bull. Soc Geol de France, 3me. ser. 1 18me. Separate, p 12 ; or J. J. Stevensox. "The coal tasln uf commentry to central France." Ann. $Y$. Acad. Scl., vol. rir, pn. 161-204, 1909. 
was not divided by a main delta deposit, and it maintained its integrity throughout, the area of deposit apparently increasing as time went on. The coal making was not confined to petty areas, but the beds formed practically continuous sheets over a great part of the surface, the Bourran and Campagnac extending to the outlet at Firmy. In Commentry, there is no coal on the delta of the Bourrus brook, the barren zone of Montassiege, or even on the deltas of the Chamblet and Colombier brooks, as defined by Fayol. Aside from some insignificant patches along the northern border, one finds coal only in the recesses between the Montassiégé and Colombier zones on one side and between Montassiégé and Chamblet on the other. But in the southeast corner of the Decazeville basin, one finds the coal crossing the conjoined deposits of the Longuefort and Haute Serre brooks - and this condition continued there throughout, for the curved outcrops of the Soulier, Campagnac and Bourran beds are shown crossing the area of stream deposit from Haute Serre to Firmy. One must bear in mind that the curved outcrops are no evidence of original form or extent of those beds; they are due to erosion of a fold with strong northward pitch. The distance from Haute Serre to Firmy is about four miles. Farther north, the Campagnac bed crosses the area of deposit as clearly as at the south.

The contrast between Commentry and Decazeville is so great that the delta theory as determined at Commentry would have to be modified in important respects before becoming applicable to Decazeville. 'Th' theory, as formulated by Favol, may he summarized thus:

The coal terralns have great analogles to present deltas; both are composed essentlally of materials carrled by streams of water; the plant beds of deltus are represented in the coal terrains by combustlbles of plant origin. In the coal terralns, as in deltas, the extent of the beds varles from a few square meters to some thousands of square kllometers; the thickness varies from a mere trace to several dozens of meters; the slze of the elements from the finest grain to blocks of several cublc meters. At Commentry, a lake sur rounded by mountains was in the place now occupied by the Conl Measures. Rain water gradually ate away the surrounding reglon, dug valleys and car rled to the lake pebbles, sand, mud and plants, which finally flled It; these are the materials which constituted the beds of conglomerate, sandstone, shale and coal making up the Coal Measures. The lake of Commentry was nine kllometers long by three wide and its greatest depth was about 800 meters. The distribution of materials depends on their speciflc gravity or flneness, as well as upon the condition of the water, whether qulet or agitated, Into whlch they are carried. The fuer, lighter elements wlll be carrled much farther tban the others before reachlng the bottom. ${ }^{10}$

\footnotetext{
"II. Fayor., "Réunton. etc " pp 14, 19, 13
} 
The essential features of the doctrine are that the basin was occupied by a deep lake into which streams brought detritus of all kinds, mineral and vegetable, to be deposited on the bottom in the order of their specific gravity, very fine mineral matter being equivalent in distribution to plant material. An important and attractive feature in Fayol's presentation is the assertion that the coal deposit accumulating on the floor of a basin may be, in its several benches, contemporaneous with deposits at several horizons on the deltz slope and thus, though resting on the floor, it may be continuous with a bed which, at the shore, is 1000 feet above the bottom of the basin. This is to explain the shoreward bifurcation of coal beds.

There is no room for difference of opinion respecting the origin and mode of deposit of the inorganic materials in 80 far as they owe their presence to the transporting power of water; the only question is respecting the origin and mode of deposit of the organic materials now found as coal beds." Unquestionably, the so-called delta theory explains satisfactorily some features of the Decazeville as well as of other basins and, regarded from this viewpoint, it has much to commend it. The flexibility and adaptability of the doctrine in the hands of some of its adherents are thought to be strong arguments in its favor; but these matters are merely secondary. When a hypothesis is presented, the first question to be asked respecting it is, Is it possible? and the second is, Is it probable? To be convinced that this double test is essential at the outset, one need only read some of the old works on cosmogony. Whiston is especially worthy of study, for his work contains not merely a vast accumulation of actual facts, but also a wealth of mathematical demonstration which apparently leaves nothing to be desired. No recorded observation, no known fact, nn phenomenon in earth, sea or sky failed as buttress to his elaborate theory respecting the origin of things. That was the panacea for perplexities in cosmogony, and its only defect was that it was based on assumptions. Equally satisfactory as an illustration is the celebrated hypothesis presented by Piazzi-Smyth respecting the great pyramid at Ghizeh, which explained the purpose of every part of that structure so heautifully as to arouse admiration as well as to carry conviction. The only objection to it is that it is based on assumptions which are not true.

\footnotetext{
u In pasing, It may be well to mention a matter of minor importance. The writer was Informed several IImes while In I lecazeville that, as the mineral detritus is due necessarily to transport, the natural conclusion would be that the Interstratifed coal had the same origtn. Those who advance this argument seem to regard it ag conclutre; but it is not so. Applied to a coral reef inclosed in sandstone or to a sunken swamp covered by aand on the New Jersey or Baltic shore, one would he fustlfled in asserting that alnce the recf and the axamp are of known in eitu origin the fnclosing and must also ife of in situ nrigln
} 
One must concede that a hypothesis might be framed which woula account satisfactorily for many conditions in a given locality and still be based on an impossibility. Before considering the applicability of the delta theory to Decazeville, one must ascertain whether or not the fundamental conditions demanded by that hypothesis existed in the region under consideration.

The Decazeville basin is very small; the earliest deposits were laid down very soon after the depression was formed, for the rocks belong to one subdivision of the Coal Measures and there is no evidence that rocks of greater age intervene between them and the Archean. The character of the Coal Measures shows that the streams in the earlier period were short and torrential; that even during the greater part of Campagnac deposition they had cut back only a few miles, had not a wide fan of tributaries, but were still more or less torrential and flowed in narrow valleys such as are seen now in and around the basin. They emptied into an at most wholly insignificant body of water, so small that during floods such as have been imagined by some adherents of the transport doctrine everything except coarse stuff would be carried directly to the outlet at Firmy, and the finer materials would be deposited outside of the basin.

Under such conditions, all citation of phenomena observed on deltas of the Mississippi, Nile, Ganges, La Plata or even of the Rhone, would be irrelevant. Streams flowing hundreds or thousands of miles through broad plains and carrying for the most part fine material in their lower reaches, along with trees gathered from immense areas by undermining of banks cannot be utilized to illustrate what a three or even 10 mile torrent, flowing over tough mica schist or microgranulite and inclosed in a narrow valley would or could or might do. Nor may the deposit at the mouth of a petty stream emptying into a pond be compared in any sense. with the delta of a vast river. In fact, the term "delta" aв applied to the theory seems to have been chosen without full consideration. Thr writer has not been able to discover in the Montassiégé area of the Commentry basin any evidence of a true delta. The deposit is rather a grealt dejection cone, largely under water perhaps, with no doubt temporary delta conditions during excessive floods, but during most of the time trenched by only one waterway. It might be well in discussing the conditions to avoid the term delta as not wholly appropriate, and to think instead of broad dejection cones such as one sees in the Rhone valles: hetween Viége and Martigny. At least one of those cones is so much like the earliest Auzits deposit in form and extent as to make not unreasonable the suggestion that the latter began as a subaërial deposit.

Another matter may he noticed in a preliminary way. The delta do- 
trine in its original form conceives of the coal basin as occupied by a lake of great depth; this no doubt to avoid the difficulty of accounting for the 2500 feet of rock by continental subsidence. But the great original depth of the depression, as shown by Delaunay, is by no means essential to the hypothesis, which without that deserves all the praise which has been lavished upon it for its ingenuity. Lemière has expended much labor and great skill in the effort to determine the forms which the deposits would assume in deep water; but that question does not concern the matter in hand, for there is no evidence whatever to support the suggestion that the basin held a deep lake; such evidence as does exist all indicates that the water area was often small and that it was never deep; that until the end of Campagnac deposition a considerable part of the basin was exposed to subaërial action ; even that the Haute Serre deposits may have been begun as a subaërial dejection cone.

The Decazeville basin embraces about 30 square miles: the entering streams, at first short and abrupt, cut back their vallevs until in the Bourran time they may have attained a length of 10 miles, sufficient to account for the whole deposit of inorganic detritus. Adding to the surface of the basin itself a strip 10 miles wide, surrounding the depression, the extreme area whose waters found outlet at Firmy would not be more than 350 square miles at the time of greatest extent. In all probability it was much less. The regetation to supply detritus for the coal beds must have been derived from that area, and the detritus could reach the hasin only by way of streams, torrential during a great part of their existence and flowing over tough, resistant rock.

The type of valley through which these streams flowed is familiar in France. The gorge between Eygurande and Bort and that between Allassac and Vigeois on the way to Limoges suffice for illustrations of cutting in the schists. One has only to vary the scale in order to have all the features shown by the Decazeville streams in the several stages of their development.

The work around the basin was confined at first necessarily to corrasion, and erosion made slow progress. But it may be that disintegration of the upland rocks was rapid and afforded material in which vegetation quickly became as luxuriant as at many places between Montlucon and Viviez, within the schist area; that even the walls of the early valleys were covered by a dense growth, such as is seen in close gorges within the same area. One may well imagine this condition, since the Coal Measures flora is taken to be proof of a warm and rather humid climate. One may picture to himself the upland region as covered in great part by a forest, its surface imperfectly drained and its borders indented by short, abrupt streams. 
But one is con Ironted at once by serious difficulty in the effort to apply the doctrine of transport. The Soulier-Abiracs bed rests almost directly on the lowest deposit of the Auzits system; its curved outcrop is from one fourth of a mile to a mile and a half from the schists, so that the coal must have covered much of the space inclosed by that outcrop; it may have been spread over four square miles, or even more, with an arerage thickness of three feet. While this bed was accumulating, the three streams of Longuefort, Haute Serre and Lugan must have been utterly insignificant. The Campagnac coal bed had an area of at least 12 square miles with an average thickness of 35 feet; the length of the streams, outside of the basin, may have become as much as six miles. The Bourran coal bed was formed when the whole basin was receiving deposits, so that its material must have come wholly from outside, from an area of not more than 300 square miles. One can concede that enough vegetable matter, several times over, was produced on the drainage area to form the coal beds and, at the same time, he would be justified in doubting the possibility of its transference to the basin. Of course, every one knows that small streams at all times carry twigs and leaves and that they carry larger fragments during flood; but that is nothing, for one is concerned here not with patches of carbonaceous matter but with coal accumulations 70 to 100 feet thick.

Rainfall, even when heavy, does little toward shifting the regetation growing on steep slopes, unless the rock material be loose, in which case landslides may occur; but those are of limited extent, even when greatest. If there be a coating of humus, the effect of the rain is practically nothing. It is unnecessary to go far from Decazeville in search of proof.

At Viviez, two miles away, fumes from the zinc works have destroyed almost all regetation on the abrupt hillslope alongside ; rains have already gashed the face deeply and the cover of disintegrated rock is accumulating at the bottom. The limit of the devastated space is defined sharply; southward from it the vegetable cover remains, and the surface is uninjured. This protective power of humus is familiar. That material accumulates under forest cover everywhere, even on very steep slopes; it absorbs water and then coheres tenaciously. Studies made near New York in the effort to solve the problem of water supply for some towns prove that the humus coating is permanent on exceedingly steep slopes and that water from such slopes is limpid, practically free even from regetable matter. The hills bounding the gorges below Eygurande and above Allassac have slopes often reaching 30 degrees and sometimes exceeding that angle, while walls in railroad cuts frequently approach the vertical. During the summer of 1910 , the rainfall in that portion of France was 
unusually great, and the numerous showers were almost tropical in violence; water swept down the hillsides in sheets and petty rivulets were converted into torrents. Yet one traveling through those gorges on the railroad cuuld see little trace of destruction-even the plants growing on the walls of cuts were uninjured.

As the Carboniferous climate is supposed to have been tropical or subtropical, reference to conditions observed in the tropics is proper. The writer has had opportunity to examine at close range fully 100 miles of the Venezuelan coast, much of western Trinidad and about 50 miles of the Jamaican coast. The slopes in Venezuela and Trinidad are abrupt, and the strata are often inclined at a high angle. Landslides are not rare, and they always leave a broad scar on the face; but elsewhere the only evidence of heavy rainfall is an occasional gully in yielding rock; the regetation is practically intact on the steepest slopes. Jamaica illustrates well the relations of rock, rainfall and vegetation. Near Kingston, the rock is a yielding slate on which vegetation can hardly secure a hold; the rainfall is but 30 inches per annum, yet the slopes are gashed. Eastward, where the rock is better, one sees an occasional gully and here and there a landslide; but for the most part the vegetation is very dense. Where trees have been burned off, Guinea grass has taken prompt possession of the surface on even the steepest slopes, giving great spaces of bright green which are notable features of the scenery. During Norember of 1909, the rainfall in the mountains of the island was excessive, there having been at one locality a fall of 120 inches in eight days, while there were falls of 20 to 30 inches within 24 hours at many others. Banana plantations, with unprotected soil, were washed down the hills and the plants became projectiles with which the flood destroyed vegetation on the lowland; but the cocoanut forests remained almost uninjured and the litter of vegetable debris covering the ground under them was not disturbed. Where the surface was protected by vegetation, the damage was confined to gullies dug by fallen trees pushed forward by the water. These gullies widened in anft material and trees tumbled into the torrent were carried down to the lowland, where they were deposited pêle mêle with mineral detritus over the cultivated area. ${ }^{12}$

It would seem altogether probable that rainfall on slopes along atreams could do little toward forming the coal beds of the Decazeville basin. But on the great rolling upland area, drained by the streams and covered by forest growth, the decaying regetable matter accumulated during a

\footnotetext{
II am under obligation to Mr. C. Leslie Mals, C. E., of Eingston, for statistics of rainfall in Jamaica, and also for Information respecting localltles which 1 could not visit.
} 
long period and formed a thick coating of hamus, which, torn off by a mighty flood, might be carried into the basin, there to become coal. It has been suggested many times that such removal would be necessary in order to maintain continued growth of the forest, there being something in humus which is repugnant to trees.

The latter suggestion should be considered first, for it has been urged as showing that the transport doctrine is the necessary explanation of a thick mass like the Bourran bed, almost unbroken by partings. But it is due to a misconception of the conditions. Plants do not find repulsive materials in humus. Almost 150 years ago, De Luc wrote in one of his letters that the old fortifications of Oldenburg, made of material taken from the swamps, were covered with trees showing remarkably luxuriant growth. It is well known that advancing swamps destroy forests by obstructing the drainage, so that the trees are literally drowned by the increasing moisture. There are many plants, among them some trees, which not only endure the moisture, but even thrive in the moist humus; some indeed attain their best estate only when growing in the humus itself. The cedar of the New Jersey swamps, as shown by Cook many years ago, yields its finest wood only where the roots do not reach the subsoil ; for where the swamp is shallow and the roots penetrate the underlying beds only inferior wood is produced. The vast thickness of apparently uninterrupted coal in the Bourran bed is in no sense an argument in favor of origin by transport; on the contrary, it may be an important argument against the doctrine as applied to the Decazeville basin.

The floods, upon which some authors lay great atress, could do little along the lines of the streams, even were the valleys as wide at bottom as are those now crossing the basin. It is true that large streams in flood carry houses and logs, but those are, so to speak, only loose materials lifted from open spaces. Transported trees are merely those which have fallen into the water from undermined banks. But along the streams entering the basin, the amount of vegetable matter available for removal could be in only insignificant quantity. The area with abundance of regetation was mostly in the forested upland region, which is supposed to have been a rolling surface, ill-drained in portions, with broad rather deep swales in which at times the water would collect and flow with increasing force, these conditions being most favorable for accumulation of humus or halfdecayed vegetable matter. This humus cover on the upper surfaces could not be affected by the moving waters; the only spaces to be considered are the lower broad hollows falling toward the streams, through which the mass of water would tend to flow rapidly.

One must recognize that the conditions observed in floods of the Seine 
and Loire are not the same as those probable in the region under consideration. Those rivers rise in the highlands and flow for a long distance through a plain country. Yet there are resemblances and the movements of the water are much the same. The devastation produced by rainfloods is not brought about by the moving water directly, but by the material which is carried, and that is collected by the way. In any case, the water does not come down as a high wave, but with the face rising gradually up stream. No matter how rapid the rise of a rain-flood may be, it is gradual, and only loose materials lying on the surface are gathered up to be carried off. When deep, the water moves slowly below, rapidly above. If the flood pass over a forested plain, its speed is checked in flowing through spaces between the trees, and practically the only injury done is by deposit of mineral material. Even when a flood passes over meadow land bordering the stream the destruction is by burying the soil, as every one knows who has observed the conditions on rivers subject to floods. After a high flood on the Connecticut river, the maize growing on unprotected soil of the "bottoms" had not been washed away; but the rapidly moving water at six feet above the ground had pushed against the spreading tops and had overturned the plants, which lay spread on the surface. The peat bogs existing in many places along the sides of the river have been exposed to floods, great floods, for centuries, but they are intact except along the border, where undercutting of the loose material on which they rest has caused portions to fall into the stream and has made the edge ragged. Kuntze has told the same story about the great peat areas of the La Plata region.

That the running water of floods is not the direct cause of destruction is certain. Every one has observed little islands in streams subject to floods, islands covered with trees, though in flood time these may be submerged for a brief period to the depth of 10 feet or more. The streams issuing from the eastern face of the Rocky Mountains are given to frequent rise of 10 or more feet, the rise being very sudden, yet many of them have wooded islets, most inviting camping places for the inexperienced traveler. Above Vigeois, between Brive and Limoges, the stream has been dammed. Near the head of the pond, the writer saw in 1910 a young tree about eight feet high growing midway in the stream in the cleft of a large rock fragment and only a few inches above the level of the water. That tree had resisted the floods of at least five years, and some of the floods in that torrent must be extremely violent. Unless the stream be loaded with débris, it can do little damage to the flooded area ; it will not tear up peat bogs, it will not remove the humus, it will do insignificant injury to a forest. 
It is evident that conditions necessary for serious destructive work could not exist in the upland area under consideration. In that area, covered by dense vegetation, the waters would collect slowly in the lower portions; flowing from the humus-covered surface under the forests, they would be almost limpid and with no mineral detritus, carrying only such chance stems as had escaped entanglement while floating through the forest. Even in the broad hollows the flow would be impeded by a dense growth of herbaceous plants, so that rapid movement could be attained only when the water reached the streams; and there alone could a load of detritus be gathered with which to do cutting. There is no conceivable mode whereby vegetable matter growing densely on the upland could be conveyed to the basin.

In this connection another matter requires consideration. The Bourran coal bed, not less than 90 feet thick at Decazeville, is a practically continuous mass, unbroken by persistent clay partings, and it extends with decreasing thickness over much of the basin. No matter which theory of formation be accepted, transport or in situ, one must recognize that the accumulation of such a mass would require a great length of time. If one accept the transport theory, a great area is essential as source of supply, and equally a vast period of time. The suggestion that a single flood might provide material for a coal bed, by bringing down vegetable débris which had accumulated during a long period, involves insurmountable difficulties. The total area tributary to the basin could not have exceeded 350 square miles; the material for the Bourran coal bed would require a cover of humus at least 20 feet thick over the whole area, and this would have to be removed by a flood of a type unknown and operating as no flood of modern times acts, for the whole mass from the whole area would have to be brought down. The suggestion, moreover, is not consistent with an argument offered by its author in support of the delta theory. for it demands a thickness of humus which would be fatal to growing plants. In any event, one can readily see that the inpouring of a flood so terrific in extent would chum up the little lake and all light materials would be driven at once to the outlet, to be deposited far outside of the basin.

It is equally difficult to understand how the great bed could be formed by gradual deposit of transported vegetable matter during the vast period of time. One is told that during formation of the sterile deposits. the streams concentrated their attention upon inorganic materials and that during the great foods, they concentrated their attention upon vegetable matter. Such intelligent discrimination on the part of running water is incredible. 
One may not appeal here to Fayol's ingenious explanation of condilions observed at Commentry, for thuse conditions do not exist in the llecazeville basin. In the former basin, the bifurcation of the Grande (ouche toward the shoreline is rerarded as evidence that while the delta advanced, coal was deposited continuously in the basin beyond, but the deposition was interrupted on the delta slope; so that several thin beds, widely separated at the shore might be one far out in the basin. That explanation is not available for lerazeville, for no such relation exists between the coal beds there, the greatest intervals between them being in the central and eastern parts of the basin.

Whatever may or may not be the worth of the Fayol doctrine respecting the formation of coal beds as applied to other localities, the fact remains that the fundamental requirements of that doctrine do not exist in the Decazeville region. The doctrine is wholly exact when applied to the accumulation of inorganic materials, but one must look elsewhere for in explanation accounting for the accumulation of the coal beds, an explanation consistent with phenomena known to have existed at many periods in the earth's history and known to be existing now. Ind this is found only in the dortrine of origin in situ.

\section{HISTORY OF THE DECATEVILIE BABIN}

In the later portion of the Carboniferous, a triangulas block of schist and coarse granite was dropped within the three limiting faults, with its surface sloping gently toward the southeast, thus giving a slight depression, in form of a gaping fault. Midway on the eastern side, near the present village of Firmy, there seeme to have been a valley, eroded by a preëxisting stream, and with fonor still helow that of the depressed area. The vertical displarement, small at first, was sufficient to disturb the drainage, for streams entering from the south evidently originated at this time. Water from all sides escaped throngh the outlet near Firmy. while detritus was dropped on the horders. The especial line of weakness was alnng the southeastern side. where subsidence continued until the foor sank beneath the ontlet valley and water accumulated to form a pond with an area of several square miles. The little streams carried their loads into the pond. filled it and flowed acrose the newly made land. The finer materials, spread during finod time over this area, converted it into a muddy flat, of which plants tonk posession. During extremely snw subsidence, vegetable débric acrumulated in the awamp to form the Soulier-Ahiracs coal hed. Conditinna favoring such growth and accumulation ohtained first where the Hante Serre and Iugan depoits were confurent, and thenere ther extender slowly in earh direstion. 
But the subsidence became more rapid along the eastern border, the Jand surface sank below the outlet, the pond was formed anew and with gradually increasing ares. Evidently the movement was enough to disturb the little streams at the southeast, to render them torrential, so as to sweep out the pebbles, large and small, which had accumulated, an well as to provide a continuing supply. But this condition was of comparatively brief duration, and one finds above the feldspathic conglomerate a recurrence of shales and more or less coarse sandstones. Once more the area is one of muddy flats, but much larger than before. This condition was reached first between the Enne and Riou Mort, where the marshy growth which was to give the Campagnac bed originated. There the streams from north, east and south had dropped their finer materials and thence the marsh expanded, until it reached the border on all sides of the swampy area. Whether or not it extended to the southeast corner cannot be determined. In any case, the subsidence was irregular in that part of the basin; the Haute Serre brook was more or less torrential for considerable periods, and the advance of the Campagnac marsh across it: deposits was interrupted several times. The Haute Serre and Ionguefort streams covered the swamp again and again with more or less coarse deposits, so that the bifurcation of the bed as it crosses the area of deposit is one of the most interesting features observed in the basin. But this condition had ceased practically at an early period in the history of the Campagnac coal bed. The rest thickness of that bed in the central part of the area and the decreasing thickness in all directions suffice to show that the great marsh had its origin near Cransac. The gentle subsidence was long-continued, permitting the accumulation of more than 100 feet of coal.

One would expect to find that so long a period of comparative quiet was followed by one of rapid and extensive adjustment, and in the basin of Decazeville the expectation is fulfilled. Subsidence, still mostly in the rast and south, again brought the swampy surface below water and it was invered with a thin coat of fine detritus. The streams became torrential at the east and south, pushing their loads of coarse material into all portions of the flooded area. The water was always of moderate depth, frequent shale beds show that the streams were often sluggish, while occasional deposits of coal and coaly material are evidence that here and there mud banks reached to the surface and became swamps. But for the most part, conditions were unfarorable to the development of plants, and mineral deposits continued to a maximum thickness of 750 feet. a mass practically devoid of coal. 
During this long period the water-covered area expanded, and very possibly some of the deposits in the western portion, assigned by BergeI'on, Jardel and Picandet to the Bourran system, may antedate slightly the Grande Couche de Bourran. It is wholly probable that many of the later deposits there are contemporaneous with earlier parts of the Bourran bed. Until the closing stages of the Campagnac system, the western third of the basin had been above water and its rocks had been exposed (1) subaërial agencies, while the streams draining the western border had (arried their water and their Joads to the eastern side. But toward the close of Campagnac deposition, the relative conditions were changed; the unstable east side became comparatively stable, while the hitherto stable west side subsided rapidly. While the eastern portion of the basin was becoming an area of mud flats, the western portion became a pond into which streams from that side dropped their coarse materials and the silts were carried eastward to be spread wer the emerging land. This condition continued into the Bourran.

When the area between the Enne and Riou Mort, midway in the basin, had been converted into an ill-drained plain, the swamp took possession and advanced thence in all directions, rapidly toward the east, but less rapidly toward the north and the south. The period of very gentle subsidence, following the abrupt change on the west side, was very long, sufficing for the accumulation of at least 100 feet of coal within the original area. The westem prition of the basin was filled slowly, and it seems probable that there was little addition to the swamp land in that direction, until late in the formation of the Bourran bed. The irregularities of the swamp border at the weat are proved by the clay partings in that direction, especially in the southern prolongation of the bed, where the stream deposits were confluent.

Slow subsidence of the whole block continued long after the accumulation of the Bourran bed. The streams had cut down their channels, and is they flowed over the marah, they depnsited only fine material until a thickness of at least 150 feet had been reached, in marked contrast with 'onditions succeeding the formation of the Campagnac bed. More rapid adjustment followed, the sperd of the streams was increased and the Carboniferous was closed by a deposit of moderately coarse sandstonee. There was no return of roal-making conditions. After the deposition of several hundred fent of rix.k. the land and freshwater features disappeared, and the Permian sea invaded the basin from the south and laid down its beds in practical conformity with the older series below.

The date of andesitiv eruption is somewhat uncertain. Bergeron, lardel and Picandet, who devnted inuch time to the investigation, reem 
inclined to believe that the eruptions came at different times. The rock is a notable feature in the northern part of the basin, but it is not confined to that area. Three islets of eruptive roak, in part andesite, are seen north from Lugan, which are in line with an islet of andesite in the northwestern corner, as well as with prongs of an "altered prophyritic rock" projecting from the southern border near Lugan. Cross sections by Bergeron, Jardel and Picandet as well as those by Saint-Martin show that in approaching those islets from the east, the coal is turned up toward the west. Saint-Martin's sections farther north and south, in which the eruptive rocks do not come to the surface, show similar arrangement of the coal beds. Along this line the eruptive rock is newer than the Permian, since that system is involved in the folds. The complicated structure of the basin probably dates from the issue of these rocks; the petty outcrops are only. projecting portions of a great mass below, continuous from the southern to the northern part of the basin. For the most part, the local faults and other irregularities of bedding, thought to be due to causes acting during deposit, have resulted merely from movements of softer between harder beds during the final disturbance. 


\section{PLATE XIV}

Fig. 1.-OUTCRop of boURraN coal bED at FIBMY.

Fig. 2.-Southerly end of the decazevile decouverte.

The old workings are shown in the background, with fumes due to spontaneous combustion. 

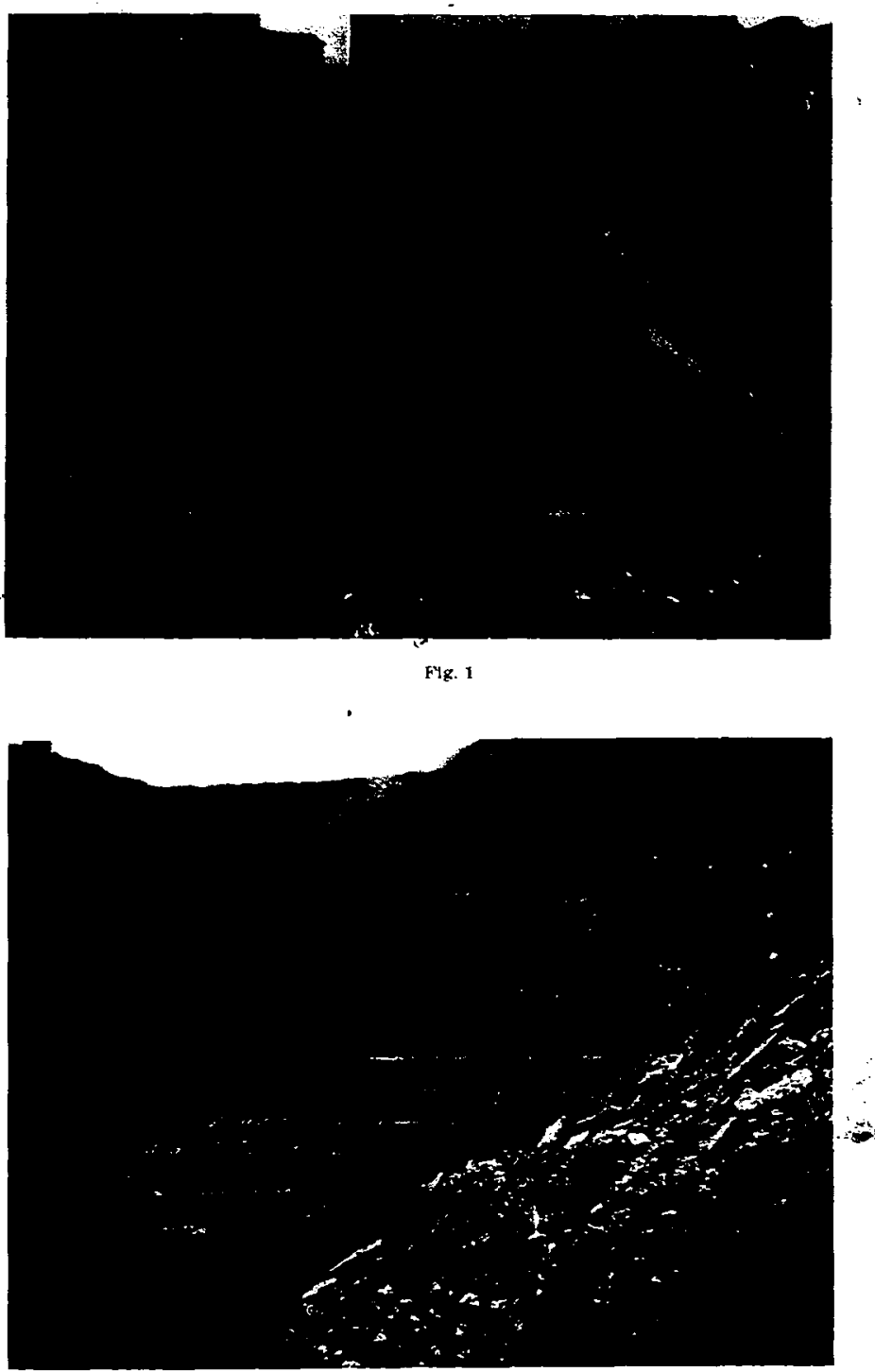

Filg. : 
PLATE XV

Fig. 1.- a "local fault" in the easteraly walt of the decazevilus DECOEYSETE

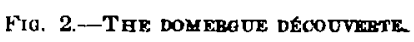

Shows effects of spontaneous combustion. 


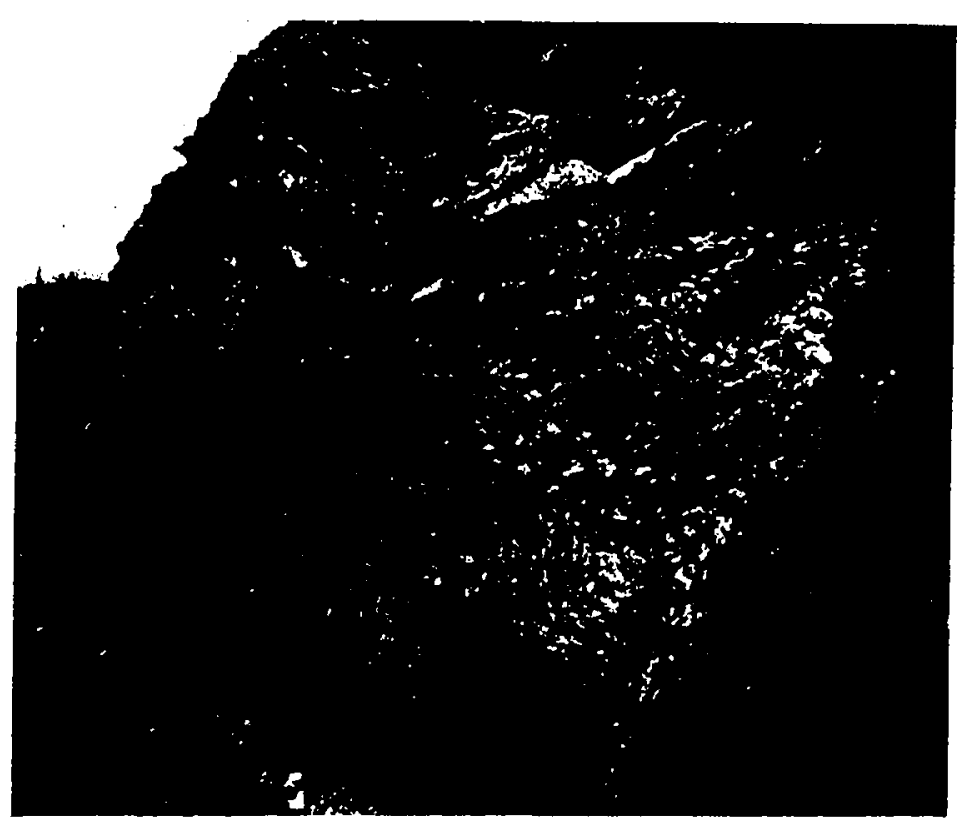

Fig. 1

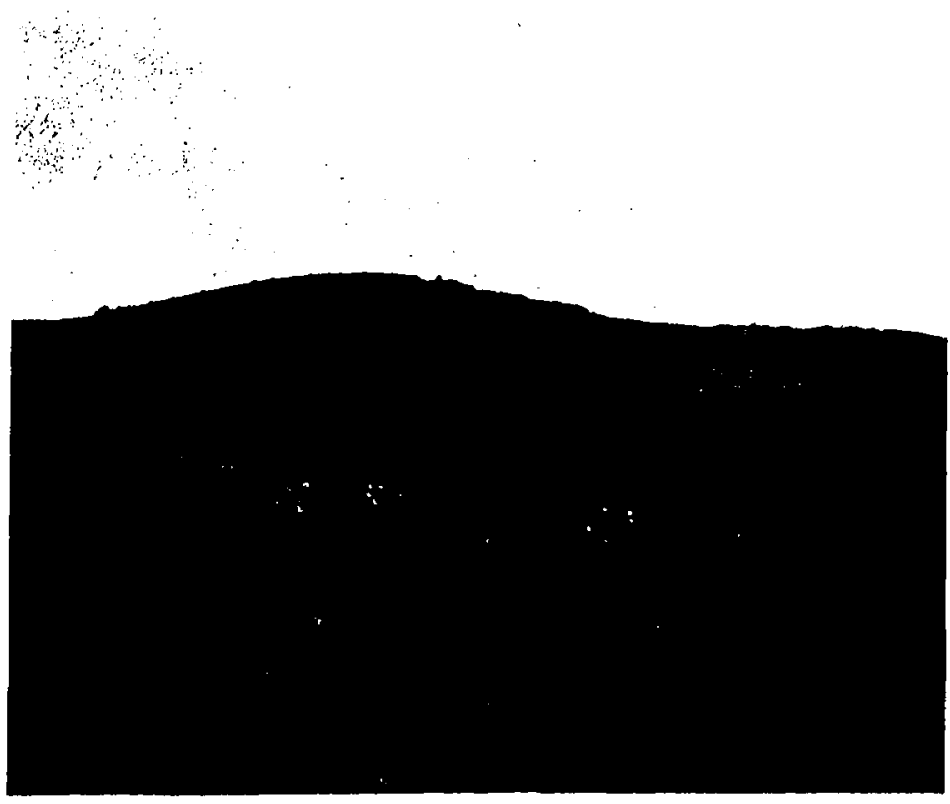

Fig. 2 